\title{
Urban Conservation Proposal: The Case of Şile Balibey District
}

\section{Betül Aydın Cura* Kemal Kutgün Eyüpgiller ${ }^{* *}$}

The Balıbey district, analyzed in the scope of this paper, is one of the important surviving districts of the area. This district of importance with its plan schemes, building materials, construction techniques and beautiful large vegetable gardens, was approved as the Şile Central Urban Site and a $1^{\text {st }}$ and $2^{\text {nd }}$ degree natural conservation site area by the Second Board for the Conservation of Cultural and Natural Heritage of Istanbul with its resolution dated 01.28.1992 and numbered 2796.

Urban space analyses were made through field surveys in order to document the present situation, identify the problems, assess the potentials and recommendations were also developed to reveal these potentials. All the buildings in Balibey district of the urban conservation site were examined, the analysis maps prepared in 1/1000 scale were synthesized and proposal maps were prepared. The present situation has been documented, and recommendations have been presented by silhouette studies plans in 1/200 scale conducted on 'Cami Street' the most well-preserved axis of the district. The plans, façade and building materials of the buildings that preserved their originality were considered on a single building scale and classified according to their typology.
Keywords: Şile, urban conservation, urban texture, vernacular architecture, timber construction system.

${ }^{*}$ Restoration Expert Master Architect, Istanbul, Turkey. ORCID

E-mail: betulaydinarc@gmail.com

*Prof. Dr. Faculty of Architecture, Istanbul Universty, Istanbul, Turkey. $\mathrm{RCID}$ E-mail: eyupgiller@itu.edu.tr 
By mentioning the legal process, suggestions were developed in order to resolve the problems which arise from interaction between the whole district and the work area in Şile, where conservation plan and reconstruction plan do not coalesce. In this work, the aim was to identify the path to be followed for the gentrification of the Balibey District Urban Site Area integrated with the city as a whole, keeping its characteristics and original inhabitants to be handed to future generations.

\section{INTRODUCTION}

This study is conducted in Balibey district of Şile, which is the third largest borough of Istanbul and had a settlement since the prehistoric times so far, according to the data obtained from the "Şile Balibey Urban Conservation Proposal" postgraduate thesis prepared in Graduate School of Science Engineering and Technology of Istanbul Technical University in 2017. First stage of the land analysis started in the beginning of September in 2016 and lasted for 10 days. Monuments in and close to the borough and preserved areas such as Hamamdere district, Üsküdar, Camcı ve Cami streets were included in the thesis and the inventory of the buildings in Balibey district was prepared. Second stage of the land analysis started in the beginning of April in 2017 and lasted for 10 days. Types of the houses and facade characteristics were assessed, facade surveys of all buildings in the north south axis of preserved Cami Street were obtained and street silhouettes were prepared.

We opted for Balibey district as the working field due to the increasing construction improper to its original texture and aimed to document the cultural property. Thus, 137 buildings and their plots in Fener Street and the parallel Cami Street were inventoried. Increasing tourism demand, abandonment of the uncared for civil architecture and the reconstruction income endanger Şile, as do they in several urban areas. This study aims to develop conservation proposals to prevent the urban texture from destruction considering the settlement up to this time, economical dynamics and life characteristics.

\section{METHODS}

Before working in Şile Balibey district, the potentials and the threats were observed and the juridical status was determined. Borders of the working field was defined according to the maps of the registered monuments, obtained from Şile Municipality Reconstruction and Urbanization Unit on 10.4.2016 and Şile inventory list, obtained from Sixth Board for the Conservation of Cultural and Natural Heritage of Istanbul on 02.21.2017. 
In the scope of the study, first the existing situation was determined. On the current map of Şile; destroyed, abandoned and damaged buildings, urban furniture, pavements and roads, and the recent buildings were updated. After analysis maps in $1 / 1000$ scale, for silhouette studies in $1 / 200$ scale in Cami Street, survey measurements were done in the conventional manner and the required intervention decisions were ascertained.

All published documents related to Şile until this time were assessed in detail. The data, acquired from theses focused on reconstruction and urbanization, were analyzed in comparison with the existing situation considering the chronology and recent information. The resources were gained from libraries, digital databases and academic platforms.

\section{LOCATION AND HISTORY}

Şile is located on the north-west of Turkey, north-east of the Marmara region and on the Black sea shore of the Kocaeli peninsula. The area of the district which is $55 \mathrm{~km}$ west of Ümraniye, one of the central districts of Istanbul, is $755 \mathrm{sq.} \mathrm{km}^{1}$ (Ertek, Kozak \& Evren, 1998, p. 3). The district center is located at the tip of a peninsula reaching out to the Black sea (Fig.1).

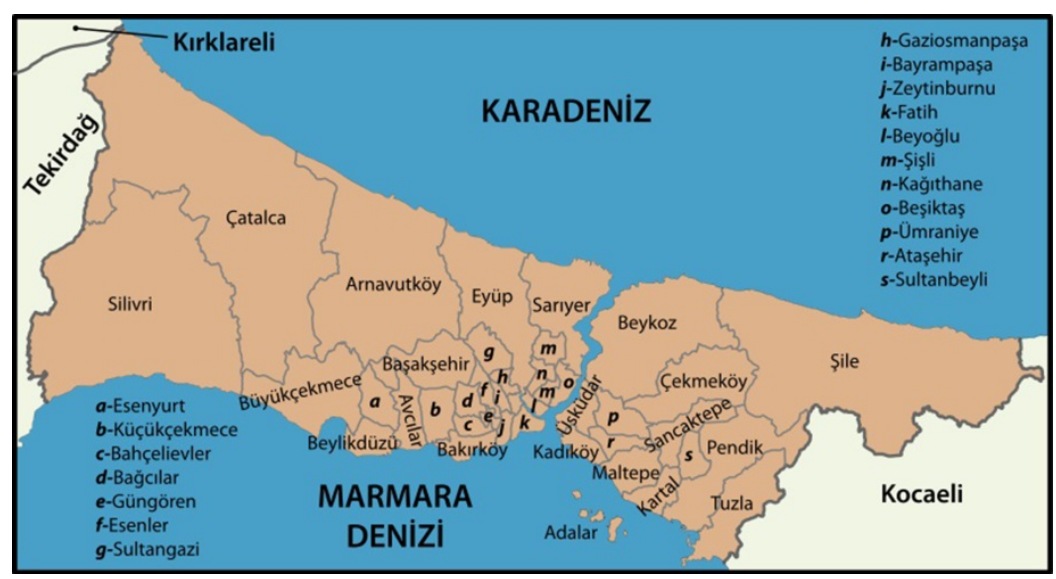

The evidence that Şile was inhabited since pre-historic times can be seen in its historical development. Tools made of flintstone that were found at stream beds during archeological excavations show that this place was inhabited during pre-historical periods of Paleolithic Period, Middle Paleolithic Period and Mesolithic Period (Özdoğan, 1982a, p. 48; Özdoğan, 1982b, p. 137; Özdoğan, 2016, p. 19). Although the finds indicate the presence of habitants in the region, remains of a settlement from the period could not be discovered (Özdoğan, 2016, p. 20; Özdoğan, 2014, p. 37).

Throughout history the Şile Region was occupied by the Hittites, Phrygians, Lydians, Persians, Bithynians, Romans and Byzantines
1https://tr.wikipedia.org/wiki/\%C \%9Eilc, access date 14.04.2016.

Figure 1. Map of Istanbul and its districts (http://www.turkiye-harita si.net/istanbul-haritasi.html, access date 29.04.2017) 
2 The meaning of Artana in the Luvi language is Land of Rivers (Umar, 2004, p. 24).

${ }^{3}$ Means "Wild Flower" in ancient Greek.

${ }^{4}$ Is described as "curved breakwater reaching the sea", "wave breaker" (Umar, 2004, p. 430).

5http://www.envanter.gov.tr/anit/ kentsel/detay/40959, access date 20.03.2017. respectively (Temir, 2010, p. 16). The district that was ruled by the Genoese and Seljuks for a short period (Ertek, Kozak, \& Evren, 1998, p. 172), has a rough period under the rule of first Byzantine, then Turkish rule.

Şile that was under the Ottoman rule for almost 500 years, was considered as the Straits Region and was transferred to British rule due to the armistice signed during the First World War (Uykucu, 1973, p. 364-365), and was retaken from the British rule on 7 October 1922 (Ertek, Kozak \& Evren, 1998, p. 176). Following the proclamation of the Republic, new municipalities were formed around the country. It is alleged that Şile Municipality, established in 1923, is one of the first ones (Aksel, 1995, p. 180).

The district and its surroundings known today as Şile was named diversely by different civilizations and these names form the source of the present name. It was called Artana ${ }^{2}$ (Umar, 2004, p. 113) in the early ages, Philee ${ }^{3}$ during ancient times, Khela ${ }^{4}$ (Umar, 1993, p. 24) during the middle ages and Şili Âșılk Paşazade and Neşri and Şilihisar in Behişti during the Ottoman period (Muslu, 1999, p. 16-17).

\section{MONUMENTAL BUILDINGS}

\section{FORTRESSES}

Şile Fortress: It is located on Block 135 Lot 1 on the Ocaklı Island (Fig.2: a, c, d) (Ertek, Kozak \& Evren, 1998, p. 262). The fortress is also named after the Ocaklı Island (Temir, 2010, p. 100). The Şile Fortress was registered on 10.07.19815. The fortress located on the crest of the hill is surrounded with fortification walls (Fig.2: b) (Firatll, 1952, p. 18). There are different opinions about the construction of the fortress. Although it is believed that the fortress is a Byzantine building from the 13th century (Ertek, Kozak \& Evren, 1998, p. 262; Uykucu, 1973, p. 365; Temir, 2010, p. 102) yet some sources state that it was built by the Genoese (Temir, 2010; Güner, 2013, p. 22). 


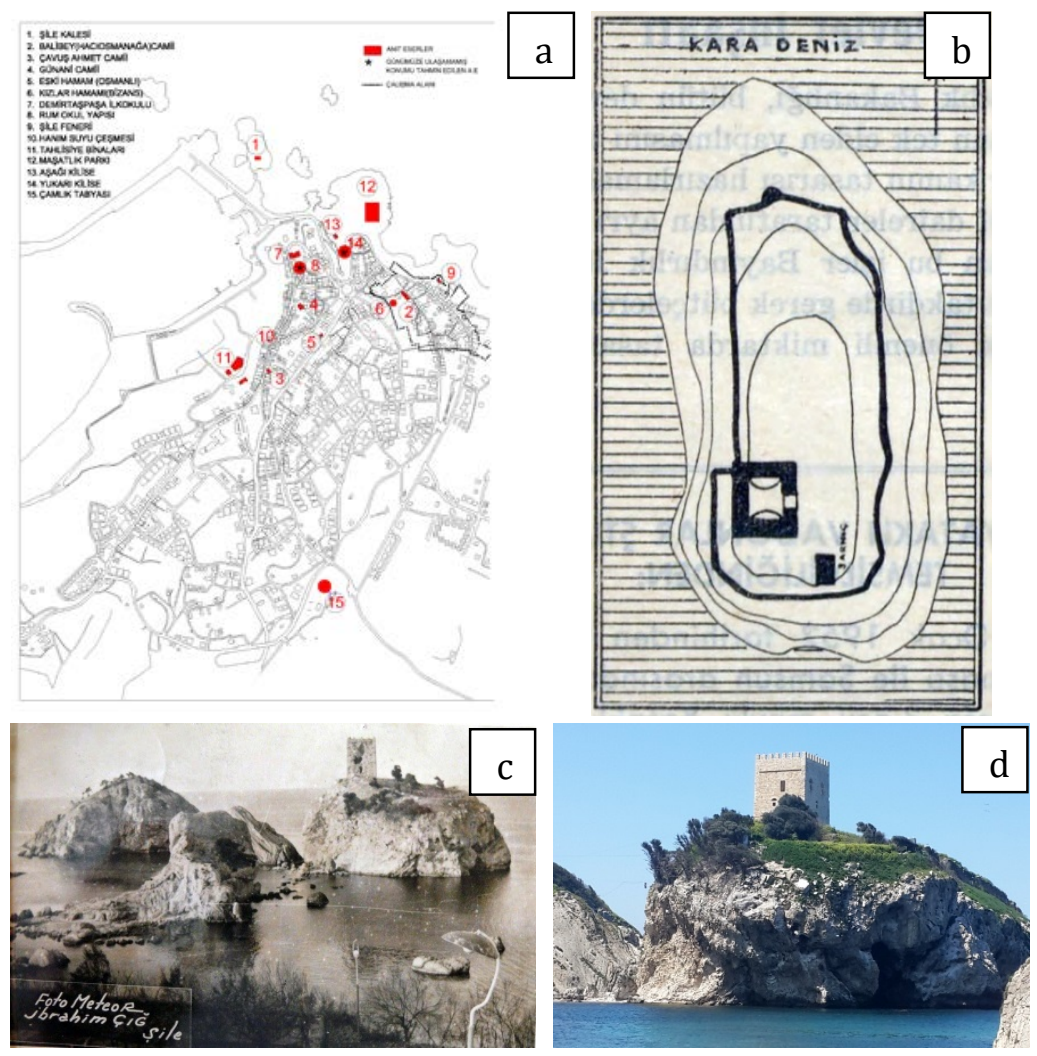

Heciz Fortress: It is located on a hill at the steep slopes of Yeşilvadi situated at the Kalealtı district of Şile (Fig.3: a) (Ertek, Kozak \& Evren, 1998, p. 262; Temir, 2010, p. 102). It is about 15 km on the Şile-Üsküdar highway (Ertek, Kozak \& Evren, 1998, p. 262). There are different arguments on who built the fortress. Even though some sources state that it was built by Byzantines against enemy attacks from Anatolia century (Ertek, Kozak \& Evren, 1998, p. 262; Uykucu, 1973, p. 365; Temir, 2010, p.102). Firatl claims that the fortress was built by the Ottomans at the end of the 14th century (Firatli, 1952, p. 20).

Sarı Kavak Fortress: It is located near Hasanlı village $32 \mathrm{~km}$ away from the center of Şile (Fig.3: b) (Ertek, Kozak \& Evren, 1998, p. 262; Temir, 2010, p.102). It is believed that it was built by the Byzantines against enemy attacks coming from Anatolia (Uykucu, 1973, p. 366; Temir, 2010, p.102; Şile Tanıtım Kitabı, 1995).

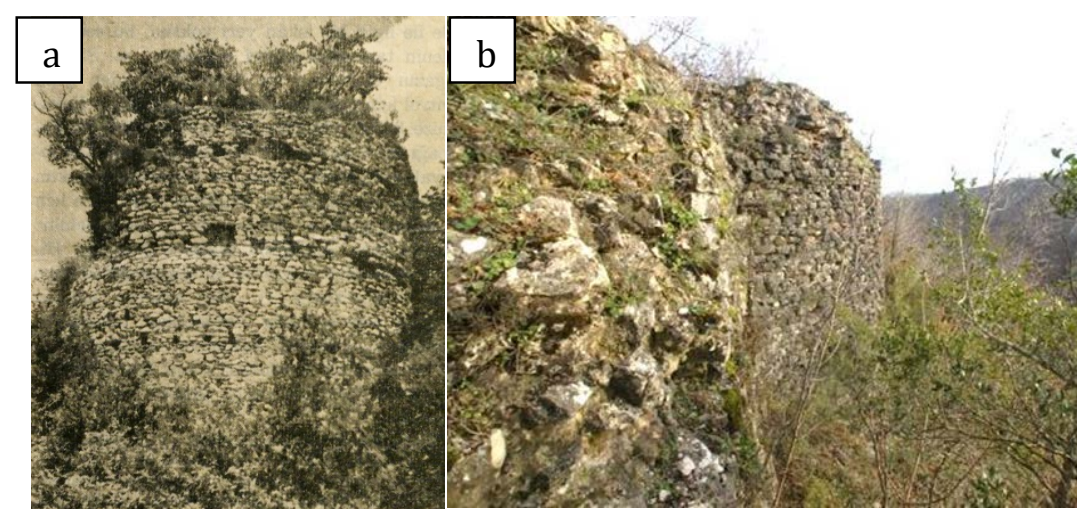

Figure 2. a) The location of the monuments in the center of Şile (Drawing: Aydın, 2017). b) Şile Fortress, fortification wall and cistern (Firatll, 1952, p. 18). c) Şile Fortress (Photo: İbrahim Çı̆̆). d) Şile Fortress after restoration (Photo: Aydın, 2017).

Figure 3. a) Heciz Fortress (Firatl, 1952, p. 19). b) Sarlkavak Fortress ruins (Photo: Bünyad Dinç; http:// www.aktuelarkeoloji.com.tr/sarikav ak-kalesi). 
6http://www.envanter.gov.tr/anit/ kentsel/detay/49137, access date 20.03.2017.

Figure 4. a) Haciosmanağa Mosque and wooden building (Photo: Aydın, 2017) b) Hacıosmanağa Mosque, mihrab and edge of the window (Photo: Aydın, 2017).

7http://www.envanter.gov.tr/anit/ kentsel/detay/49172, access date 20.03.2017.

Figure 5. Çavuş Ahmet Mosque, before and after intervention (Güner, 2013, p. 32; Picture 2.13).

8 Şile (İstanbul) Explanatory Report of Conservation Master Plan -1992.
Teksen Fortress/Citadel: It is located quite close to Akçova settlement which is near Ağva Teksen Village on the southeast of Ağva (Uykucu, 1973, p. 366; Dinç, 2013, p. 37). It is believed to be a Byzantine monument (Uykucu, 1973, p. 366; Dinç, 2013, p. 39).

\section{MOSQUES}

Balibey (Haciosmanağa) Mosque: It is located on the corner of Cami Yokuşu and Cami Streets in the Balibey District (Fig.2:a ; Fig. 4). The building on Block 48 Lot 1 was registered on 28.01.19926. The construction date is unknown.
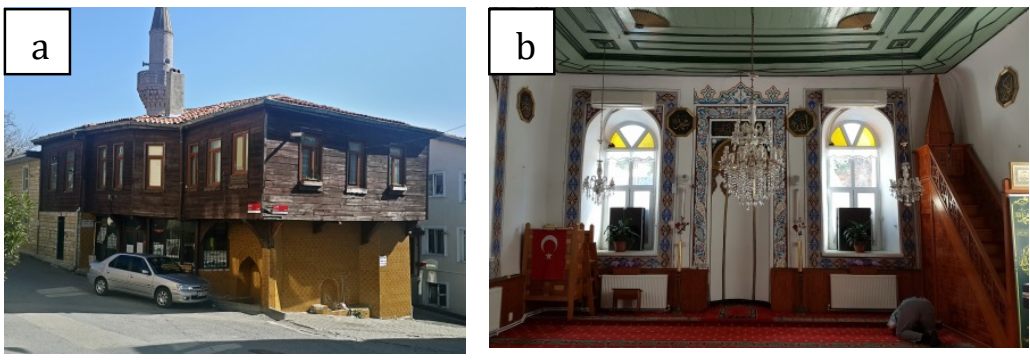

Çavuş Ahmet Mosque: It is located on Block 93 Lot 30 on the corner of Üsküdar Road and Çavuş Ahmet Street (Fig.2:a). Although the building date of the mosque is unknown it is believed to be a 20th century monument (Fig.5). The mosque was registered on 28.01.19927.
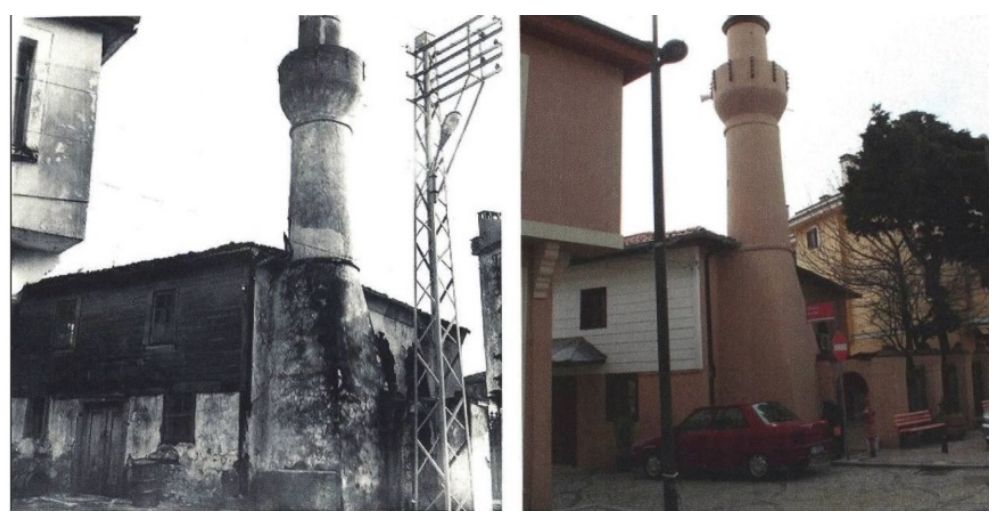

Günani Mosque: It is located on Block 16 Lot 1 opposite the present Şile Municipality building and on the corner of Üsküdar Road and Mektep Street (Fig.2:a; Fig.6). The mosque is a Republic Period monument and was inaugurated on 23 May 1952. It was registered on $28.01 .1992^{8}$. 

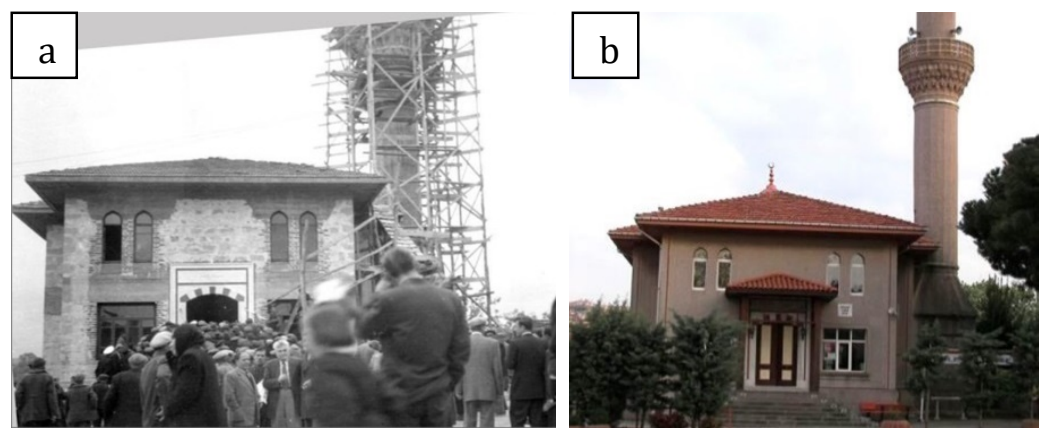

HAMMAMS

Eski Hamam (Ottoman) (Old Hammam): It is located on Block 10 Lot 2 on the Cumhuriyet Road at the Hamamdere District of Şile (Fig.2:a; Fig.7). It was registered on 28.01.19929. Although its building date is unknown, some sources state that it is an Ottoman monument (Ertek, Kozak \& Evren, 1998, p. 264; Şile Tanıtım Kitabı; Temir, 2010, p.110).
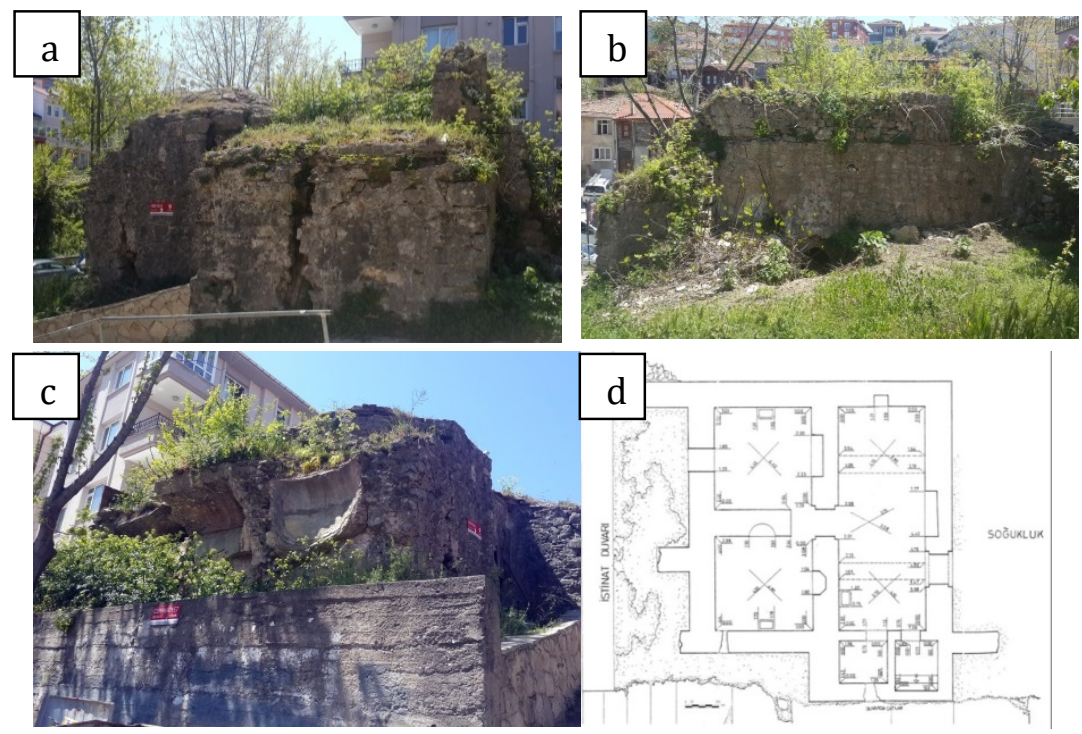

Kızlar Hamamı (Byzantine) (Girls' Hammam): These ruins believed to be from the Byzantine period are mentioned as Girls' Hammam (Uykucu,1973, p. 366; Kasar, 1987, p. 58; Teker, 1992, p. 24; Şile Tanıtım Kitabı, 1995; Temir, 2010, p.110). Its ruins are on Block 46 Lot 8 on the Cami Yokuşu Street near the Fener site (Fig.2:a; Fig.8).
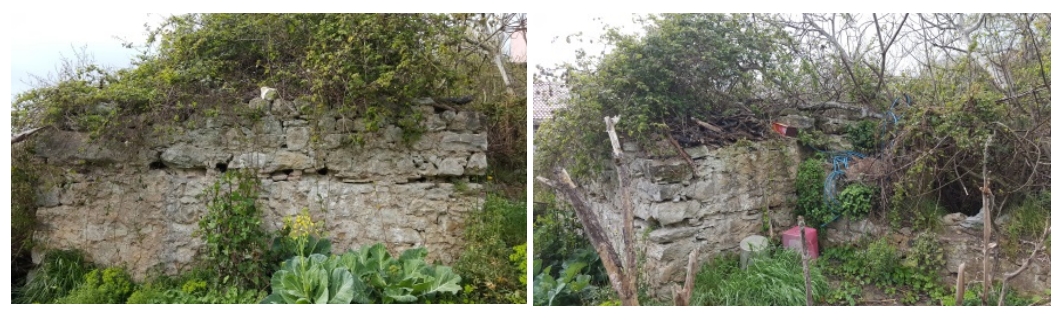

Figure 6. a) Günani Mosque 1970's (Güner, 2013, p. 32; Picture 2.14, Atllay Erge Archive). b) Günani Mosque entrance facade, 2017

${ }^{9}$ http://www.envanter.gov.tr/anit/ kentsel/detay/40812, access date 20.03.2017.

Figure 7. a) Eski Hamam (Old Hammam), 2017. b) Eski Hamam (Old Hammam), 2017. c) Eski Hamam (Old Hammam),2017. d) Eski Hamam plan (Old Hammam) (Teker, 1992).

Figure 8. Ruins of the Girls' Hammam, 2017 


\section{EDUCATION BUILDINGS}

10http://silekizteknik.meb.k12.tr, access date 20.03.2017.

11Şile (İstanbul) Explanatory Report of Conservation Master Plan -1992.

Figure 9. a) Demirtașpașa Primary School (Photo:http://silekizteknik. meb.k12.tr). b) Demirtaşpaşa Primary School, 2017. c) Map of Şile in 1920 (German Archeology Institute).

12http://www.envanter.gov.tr/anit /kentsel/detay/49128, access date 20.03.2017.

Figure 10. a) Şile Lighthouse (Photo: Mustafa Ünal 1941). b) Şile Lighthouse (Photo: Anonymous). c) Şile Lighthouse, 2017.
Demirtaşpaşa Primary School (Ottoman school building): It is located on Block 136 Lot 1 (Fig. 9: a,b) where the Üsküdar Road meets the harbor in Haclkasım District (Teker, 1992, p. 27; Güner, 2013, p. 36). It was built in 1927 and education at the school started in $1930^{10}$. It was registered on 28.01.1992 ${ }^{11 .}$

Greek School Building: This school building that could not reach today is described in the book "Şile'nin Ağıtı" (Lament for Şile) written in Athens in 1988 by the Greek writer Yeorgios Bakalakis, expatriate of Şile (Şarlak, 2010, p. 70). Bakalakis describes the location and the plan of the school in his text (Fig.2:a; Fig. 9: c).
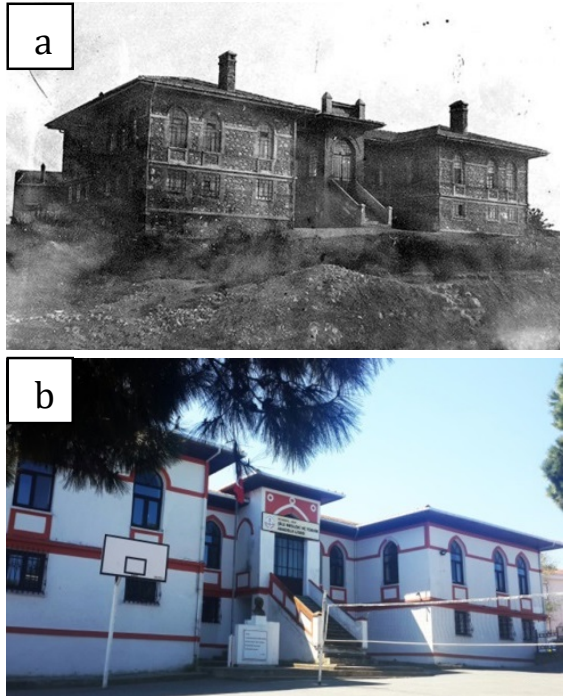

\section{OTHER BUILDINGS AT ŞILLE'S CENTER}

Şile Feneri (Lighthouse): It is located on Block 26 Lot 23 in the Balibey District (Fig.2:a; Fig.10) and was registered on 28.01.1992 ${ }^{12}$. The lighthouse was built by the French and was put into service in August 1859 (Kolçak, 2010, p. 94; Seri, 1994, p. 23). The Şile Feneri, which is a routing lighthouse (Demirel, 2011, p. 24; Toroslu, 2009, p. 76), is serving as a museum exhibiting components of its original system since 2004 (Temir, 2010, p. 97).
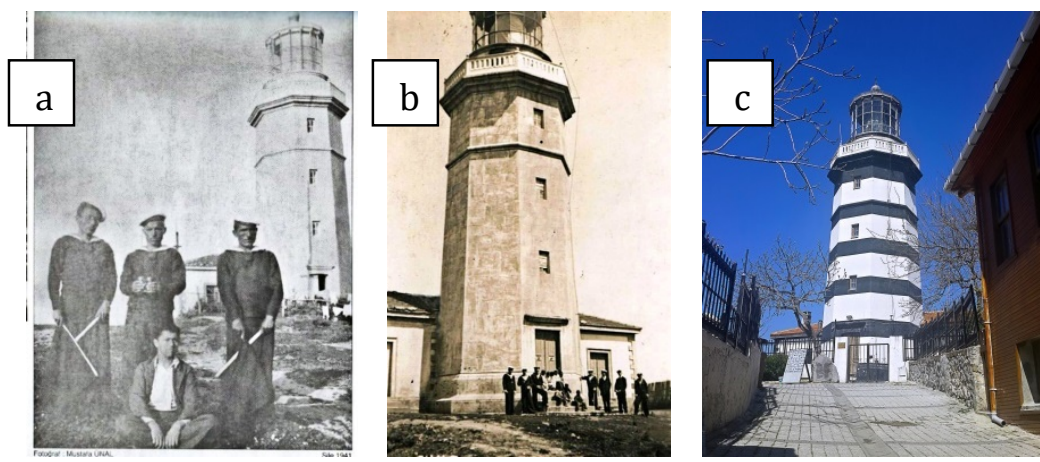
Hanım Suyu Fountain: It is located in the center of Şile on Lot 27 on the corner of Üsküdar Road and Çavuş Ahmet Paşa street (Fig.2:a; Fig.11) and was registered on 28.01.199213. It is believed to be built in 1871 (H.1287) as a charity under patronage of Mısırlı Hatice Hanım during the Ottoman period (Uykucu, 1973, p. 366; Ertek, Kozak, \& Evren, 1998, p. 263; Temir, 2010, p. 106).
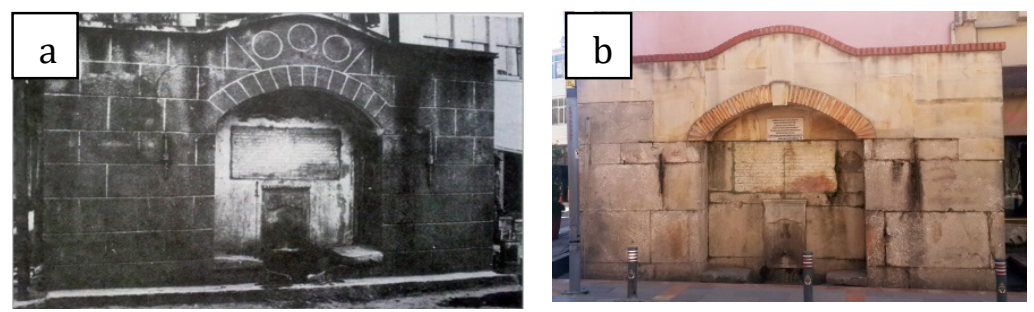

Salvage Buildings: They are built on the foothills of the slopes facing the Şile Harbor (Ertek, Kozak, \& Evren, 1998, p. 266). It is registered that these buildings were built in 1883 following the establishment of the Ottoman Salvage Administration in 1869 (Aygün, 2010, p. 82). The salvage buildings comprising stations, barracks, boathouses and rocket-houses are located at different parts of the town. The Şile Salvage Buildings lost its lifesaving functions with the landfills made in front of them during the construction of the harbor (Fig.2:a; Fig. 12).
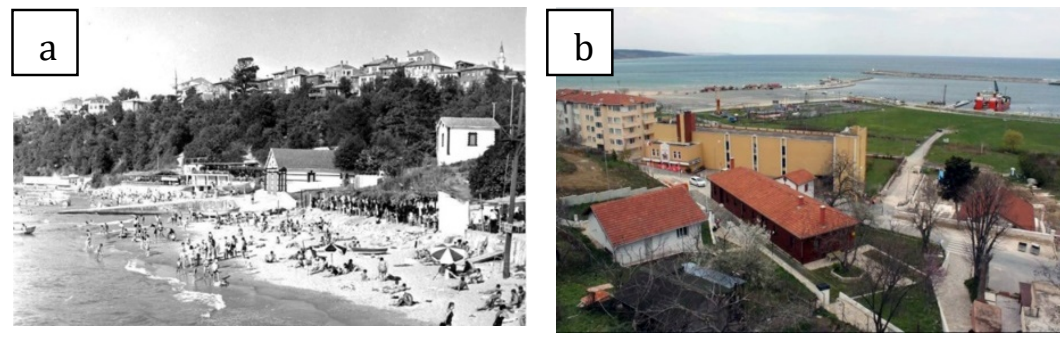

Maşatlık Park (Greek Cemetery): Today there are ruins of walls not higher than 1,5-2 meters on the non-Muslim cemetery area located on Lot 22 at the tip of Fener Road in the Balibey District (Fig. 13) (Ertek, Kozak, \& Evren, 1998, p. 264; Muslu, 1999, p. 7477). Lots 12 and 2 of the Maşatlık Park located on Block 22 were registered on 21.08.199714.
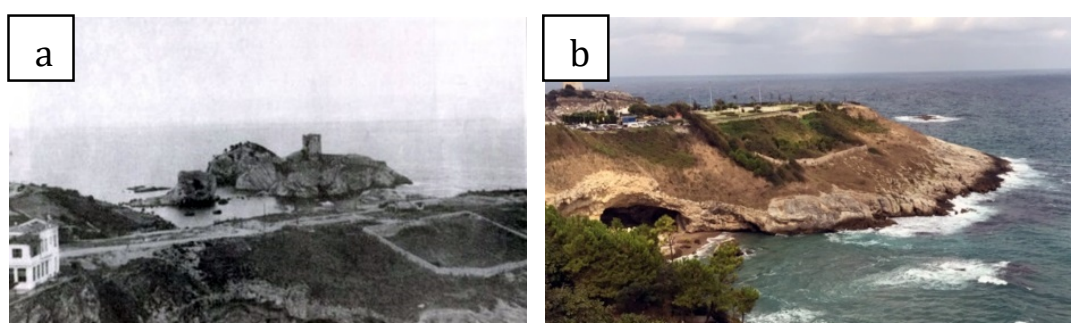

Church Ruins: Ruins found on Block 103 at the Çavuş District indicate the presence of a church. The church whose construction date is unknown is believed to have been built at the end of the
${ }^{13}$ Şile (İstanbul) Explanatory Report of Conservation Master Plan -1992.

Figure 11. a) Hanım Suyu Fountain (Photo: Anonymous, 1974). b) Hanım Suyu Fountain (Photo: Aydın, 2017).

Figure 12. a) Salvage Building before losing fuction (Photo: Anonymous, 1965). b) Salvage Building (Photo: Güner, 2013, p. 30; Picture 2.11).

${ }^{14} \mathrm{http}: / /$ www.istanbulkulturenvant eri.gov.tr/anit/kentsel/detay/4912 6, access date 20.03.2017.

Figure 13. a) Maşatlık Peninsula (Photo: Güçlüel, 1952). b) Maşatlık Peninsula (Photo: Aydın, 2017). 
${ }^{15}$ http://www.envanter.gov.tr/anit /kentsel/detay/41097, access date 20.03.2017. (There is a mistake in the inventory: although Yeniköy is written as the village, the Church ruins in the Çavuş neighborhood are described.)

${ }^{16} \mathrm{http}: / /$ www.envanter.gov.tr/anit /kentsel/detay/40797, access date 20.03.2017.

17 It is a historical motel known as Kumbaba and was built by the late Turan Aziz BELER in accordance with the natural structure of sand. It was one of the main European tourist attractions in the 1960's. Today it is being restored. Its new function will be Şile Cloth Modelling Center with hands-on training for the production of Şile cloth. It will also function as an open-air museum.

Figure 14. a) The ruins of the church (Güner, 2013, p. 34; Picture 2.17). b) Ammunition depot (Photo: Aydın, 2017).

${ }^{18}$ Cumhuriyet newspaper dated 23 December 1990 p: 15 (Tapan, M. 1990). 19th century. These ruins were registered on $03.02 .2006^{15}$ (Fig.2: a; Fig.14: a).

Çamlık Redoubt and Arsenal: There are ruins of an arsenal where the ammunition of the redoubt was kept and a position area and a cistern next to an old reservoir in the park (Fig.2:a) located on Block 70 Lot 3 at the Üst Çamlık Area of the Çavuş District (Fig.14:b). The building ruins are believed to be 100-150 years old. The park belongs to the Treasury and was registered on 22.12.199216.

In addition to the immovable cultural assets in Şile, there are quite a lot of movable cultural assets. Yüksel Özden Antik Park and Kumbaba ${ }^{17}$ Touristic Facilities located on Block 23 Lot 29 are places where archeological finds from the vicinity of the town are exhibited.
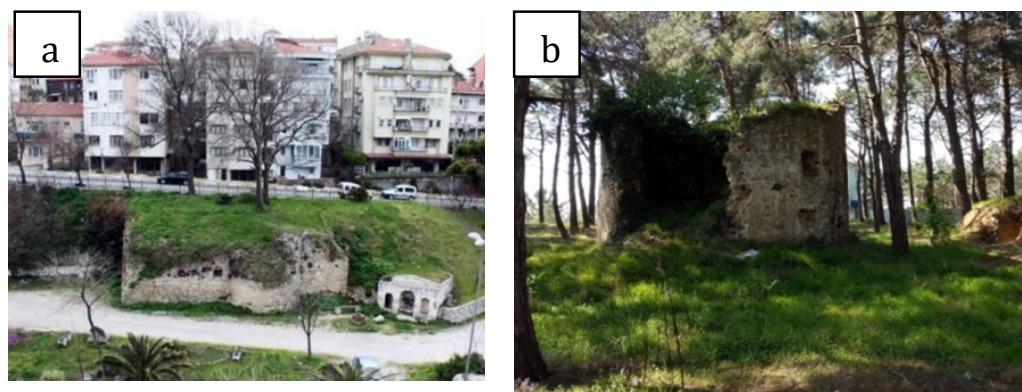

\section{PROTECTED AREAS}

The initial site decision for Şile was taken to prevent irregular settlements around the Şile-Istanbul highway and to protect Şile from becoming a dense housing area outside the tourism season because of the easier and shorter access to Istanbul. Prof. Dr. Mete Tapan, who at the time was a member of the conservation board, in an interview he gave to Cumhuriyet newspaper in 1990 stated that the new Şile-Istanbul highway under construction would in the future cause a rapid housing development in Şile and emphasized that the Natural Site Decision and the Conservation Master Plan would save the future of Şile ${ }^{18}$.

Sile town center was declared urban site and Grade I and II natural site by the Second Board with a decision dated 28.01.1992 and numbered 2796. The border of the urban site comprises the area between the east of Üsküdar Road and the west of Fener Road. On the north of the settlement, the site area is framed with the new housing around Fener and the Maşatlık Mevkii (Fig.15). 


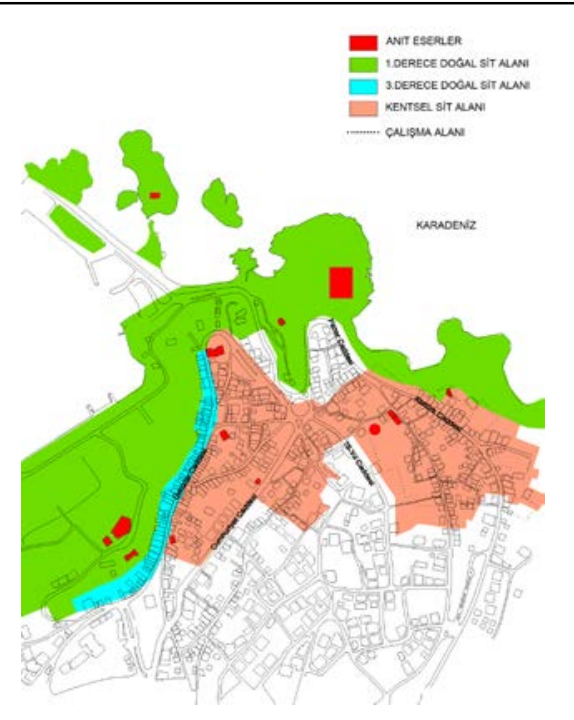

On the south, it ends where the old town texture disappears, and new development starts ${ }^{19}$. The $1 / 5000$ and $1 / 1000$ urban and natural conservation plans for the town center, published in 6 parts in 1992, were approved by the board's decision dated 22.09.1992 20 and numbered 2934. As the conservation board agreed to transform the Grade II natural sites into Grade III by a decision dated 17.09.1998 and numbered 4915, plan revisions were approved by the board decision dated 12.04.2001 and numbered 6001 (Dinçer, Enlil, Evren \& Som, 2011, p. 33).

Whereas for Şile Doğancalı and Alacalı Region the Grade I and II archeological site with an area of 96,24 hectares published in 3 parts in 1997 was approved with the decision dated 11.12.1997 and numbered 4667 (Dinçer, Enlil, Evren, \& Som, 2011, p. 40). The Domalı (Sahilköy) Göztepe Region of Şile was declared an archeological site with the decision dated 07.02.2001 and numbered 5950 . The $1 / 5000$ and $1 / 1000$ conservation plans of the site were approved by the board with the decision dated 17.03.2004 and numbered 6888. The Second Board has declared a part of Ağva settlement with an area of 20,71 hectares Grade I natural site and Grade I archeological site with a decision dated 13.04.2001 and numbered 5572. $1 / 5000$ and $1 / 1000$ conservation plans and $1 / 500$ urban design projects are approved by board decisions dated 08.01.2003 and numbered 6544 and dated 16.11.2005 and numbered 586 (Dinçer, Enlil, Evren, \& Som, 2011, p. 42-43).

Today Şile falls into the area of responsibility of Istanbul 6th Cultural Heritage Preservation Board.
Figure 15. Protected Areas of Şile Central.

${ }^{19}$ Şile (İstanbul) Explanatory Report of Conservation Master Plan -1992. ${ }^{20}$ The date in question is stated as 02.09.1992 in the Istanbul Environment Report 2008-09 (p.136) and the Istanbul Environment Report 2014 (p.161). 


\section{LIMITS OF AREA OF STUDY AND THE CHARACTERISTICS OF THE SETTLEMENT TEXTURE}

\section{LIMITS OF THE AREA OF STUDY}

The area of study analyzed in the scope of this paper is at the Balibey district situated at the north of Şile town. It forms part of the urban site area determined by the Cultural and Natural Heritage Regional Committee and comprises the immediate surroundings of Fener road and Cami Street (Fig. 16). At its north, it is limited by the cliffs that are natural borders and at its east comprises all the buildings facing Atatürk road. There are the Kızlar Hamamı believed to be from the Byzantine period, the Şile Lighthouse built in 1857, Balibey (Hacıosmanağa) Mosque believed to date from 19th century and examples of civil architecture with traditional characteristic.

Figure 16. Satellite Image of Sile Balibey District Work Area.

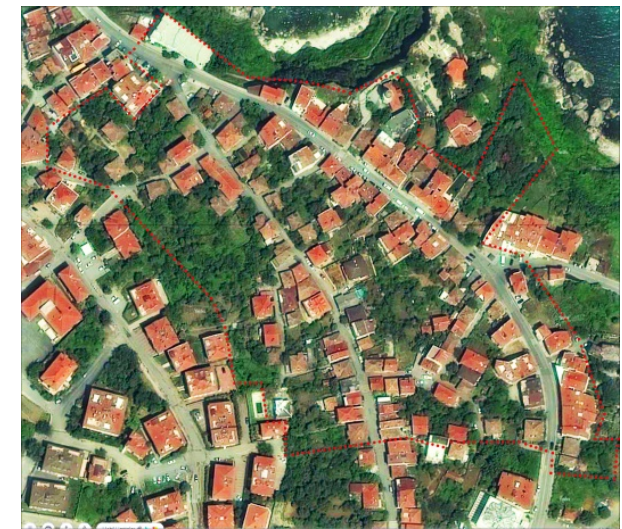

\section{CHARACTERISTICS OF THE SETTLEMENT TEXTURE}

In Şile, where the natural environment is nested with the built environment, the examples of traditional civil architecture integrated with nature and the topography forms a harmonious silhouette with its hillside and sea facades (Fig. 17). The topography, view-direction and street texture are effective in the positioning of the buildings on the terrain (Fig. 18). The buildings positioned perpendiculars to the slope are in harmony with the natural state of the terrain. The buildings face the street with cantilevers on their facades and benefit from the sea and land views with their back gardens. The street texture is effective in the positioning of buildings and footpaths and dead-ends formed according to the conditions of the terrain have influenced the rules for the positioning of buildings. Vegetable gardens and orchards have important environmental significance for the region. It is observed that most of the buildings have street facades, with rear fronts opening to quite large and sloping vegetable gardens and orchards. There are also examples of traditional houses with gardens in the area. Today, settlements 
parallel to the grade lines have caused a gradually rising texture and the housing texture along the Fener road is different from the traditional texture of the area and is formed by high-rise buildings (Fig. 19).
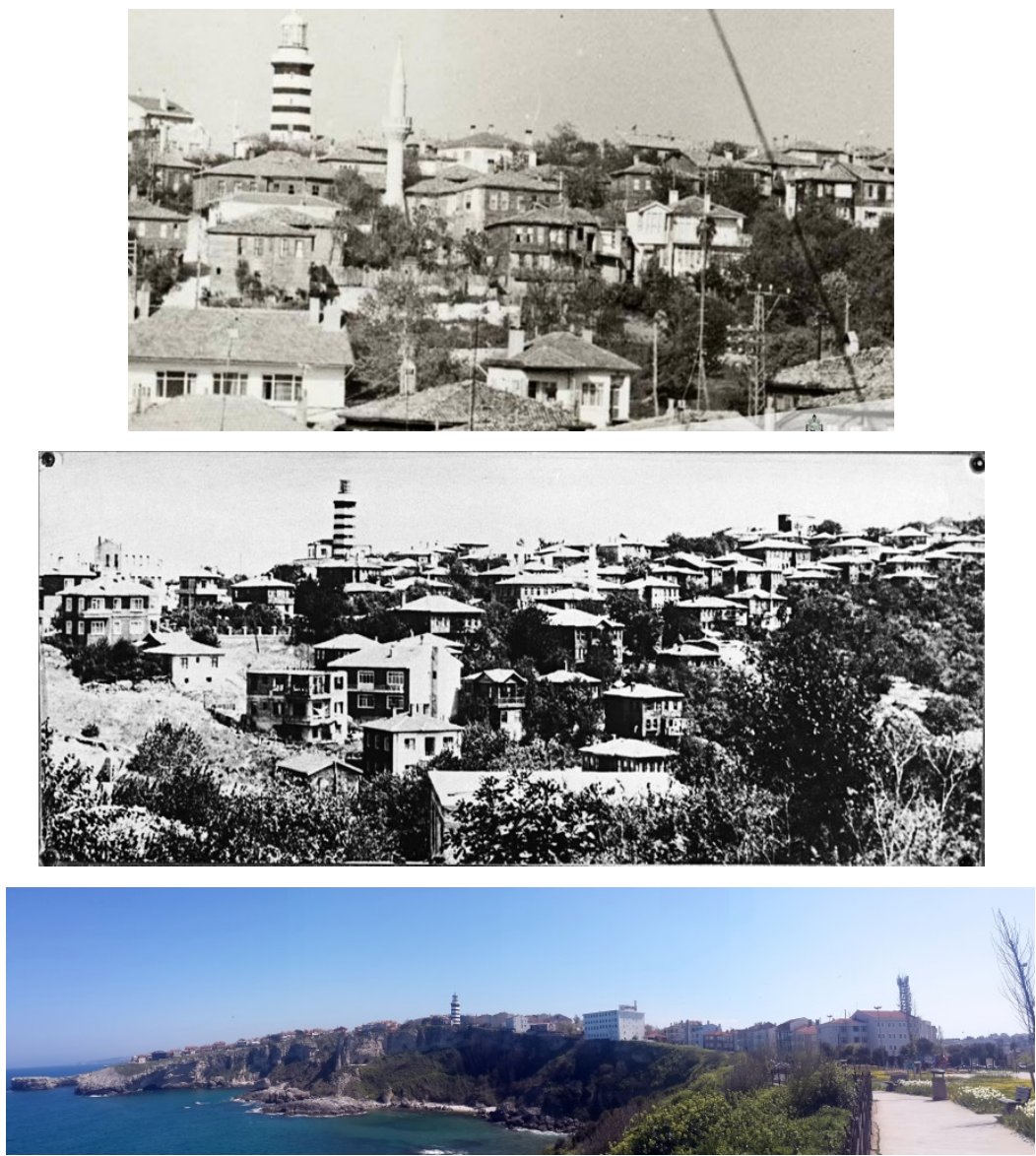

\section{EVALUATION OF THE TRADITIONAL HOUSING ARCHITECTURE}

The traditional houses of Şile are positioned on sloping and narrow streets and are generally one or two-storeys high. These buildings believed to be 100-150 years old are mostly built as timber framed houses .These buildings with extremely simple designs do not have any exterior or interior ornaments (Temir, 2010, p. 113-117).

When the traditional housing in the Balibey district chosen as the area of study is analyzed, it is observed that there are a few singlestorey buildings. The area has mostly two-storey houses. If there is a half-floor or a low basement due to the slope, this space is used as either a woodshed or winter storage. These buildings generally designed according to the traditional Turkish house plan types vary mostly according to the layouts of their facades, their rooms with cabinets and stoves, their sofas (halls) and cantilevers (Göktaș. 1992, p. 22). These houses were destroyed in time, some
Figure 17. Silhouette of Balibey District from the front slope (Photo; Anonymous).

Figure 18. Silhouette of Balibey District from the front slope (Photo; Anonymous).

Figure 19. Balibey District Coastal Silhouette from the park, (Photo;Aydın, 2017). 
were abandoned, and some lost their plan schemas and original facades through insensate interventions due to the wish to adapt to present conditions.

The pilot area chosen for conservation within the scope of the study is Cami Street. The facades of the buildings on this street were measured for measured drawings but as entering the buildings was not possible in a large part of the area, the plans could not be determined. The thesis studies made all across Şile in the past years and the Explanatory Report of the Şile Conservation Master Plan prepared in 1992 were analyzed and a new proposal for the classification of the plan and façade typologies was made according to these data.

\section{Plan characteristics}

When the traditional housing space setup is observed, it is seen that the ground floor comprises daily living space and the upper floor has bedroom units (Eraslan, 2010, p. 29; Göktaş, 1992, p. 23). The ground floor comprises a room with a stove used as the kitchen, common spaces such as the daily living room and the toilet (Göktaş, 1992, p. 23). There is a link between the sofa on the ground floor and the units of the house (Göktaş, 1992, p. 23; Teker, p. 31). The windows of the living rooms that are placed on the façade that can best see the street are at the same time designed to see the street and the entrance door. The above-mentioned room with a stove and the living room are sometimes a single unit in some examples (Göktaş, 1992, p. 23). The upper floor rooms are cantilevered to benefit from the view. There are large closets (yüklük) for mattresses, bedding, quilts and clothing. One unit of these closets that consist of three parts is designed as a bath closet (Göktaş, 1992, p. 24). As a result of the documentation study made in the area, it was determined that most of the single and twin buildings have symmetrical plans and facades with regard to their middle axis. When all data is studied it is possible to make a new classification for the plan types with respect to their sofas (Fig.20).

Single houses

-With exterior sofa (hall)

-With interior sofa

Twin houses

- With exterior sofa

- With interior sofa 


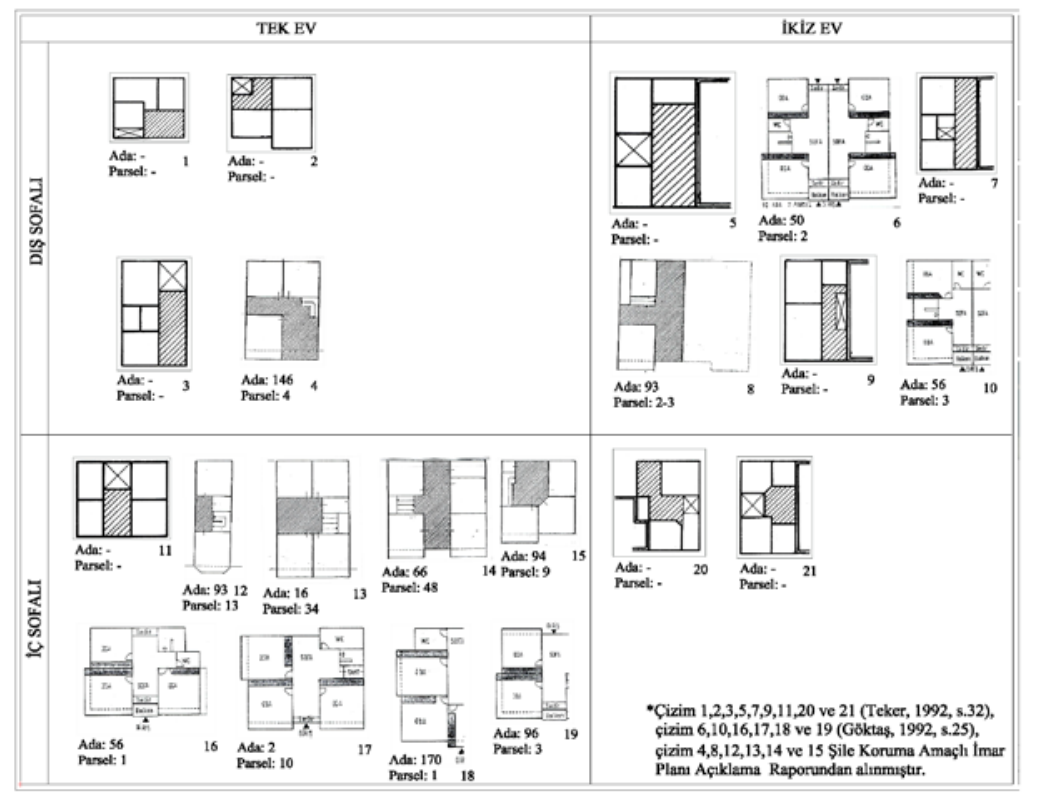

\section{Façade Characteristics}

The facades of Şile houses are generally plain and modest. In general cantilevers are designed on the first floors to add mobility to the façade and this design is realized as the reflection of the plan on the facade. There are also buildings without cantilevers in the area. Some buildings have balconies on the central axis. Instead of a door, there is only a window opening to this building component that is used for drying winter supplies. The most important reason for this is the strong winds (Göktaş, 1992, p. 26).

Weather boarding made of chestnut tree wood with dimensions of 15-20-30 cm, flat or ribbed grooved profiles are used (Fig. 21:a,b) for the facades. The boarding is used in natural form without any synthetic paint or varnish. Some buildings are whitewashed on their ground floors (Göktaș, 1992, p. 68; Teker, p. 43). Masonry garden walls made of rubble stone are usually low. The building is not hidden behind high walls (Göktaş, 1992, p. 72; Teker, p. 44). As a result of the data from different sources and documentation studies, it is possible to make a new classification for the types of façade under twin house and single house groups according to the position of the cantilevers on the façade and according to whether there is window or balcony on the central axis (Fig.22).
Figure 20. Sile houses plan typology (compiled from Teker, Göktaş and Şile KAIP). 
Figure 21. a) Facade cladding types in wooden structures (Göktaş, 1992, p. 71; Table 9). b) Facade cladding types in wooden structures (Teker, 1992, p. 42; Table 8).

Figure 22. Sile houses facade typology (compiled from Teker, Göktaş and Şile KAIP).
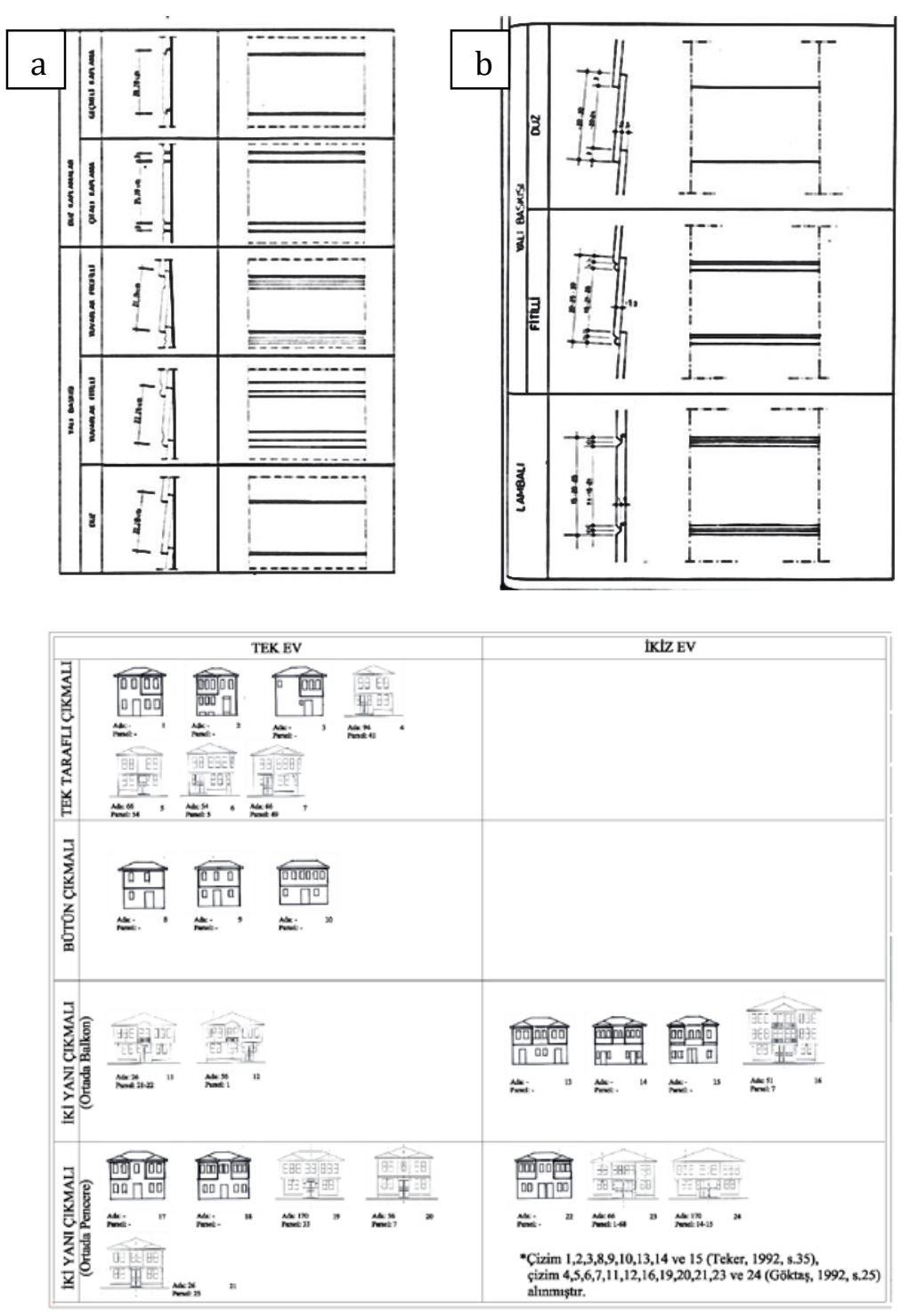

\section{Construction elements}

\section{Cantilevers}

As the buildings in the area of study are located in gardens and are detached, the wish to obtain a certain order for the geometric disorder of the plot on the first floor is not a reason for the cantilevers. The cantilevers generally protrude $40-50 \mathrm{~cm}$ from the vertical bearing elements with 45 degrees and are joined to the lower floor with buttresses with different profiles.

When the plan characteristics of the traditional housing architecture in the town is studied, it is observed that the cantilevers of single and twin houses use the axis of the central sofa as the axis of symmetry. In facades where the entrance is on one side of the façade, asymmetrically ordered cantilevers are the continuation of the ground floor movements on the upper floors. Another type of cantilever in the area is where the whole surface makes a cantilever on the first floor (Fig.23:a). 


\section{Buttresses}

The height of the buttresses supporting the cantilevers limited to $40-50 \mathrm{~cm}$ in the Şile houses vary between 50 and $90 \mathrm{~cm}$ (Teker, 1992, p. 38). All buttresses used in the traditional housing architecture are made of wood. They are different variations of certain geometric forms (Fig.23: b,c) (Göktaş, 1992, p. 50).
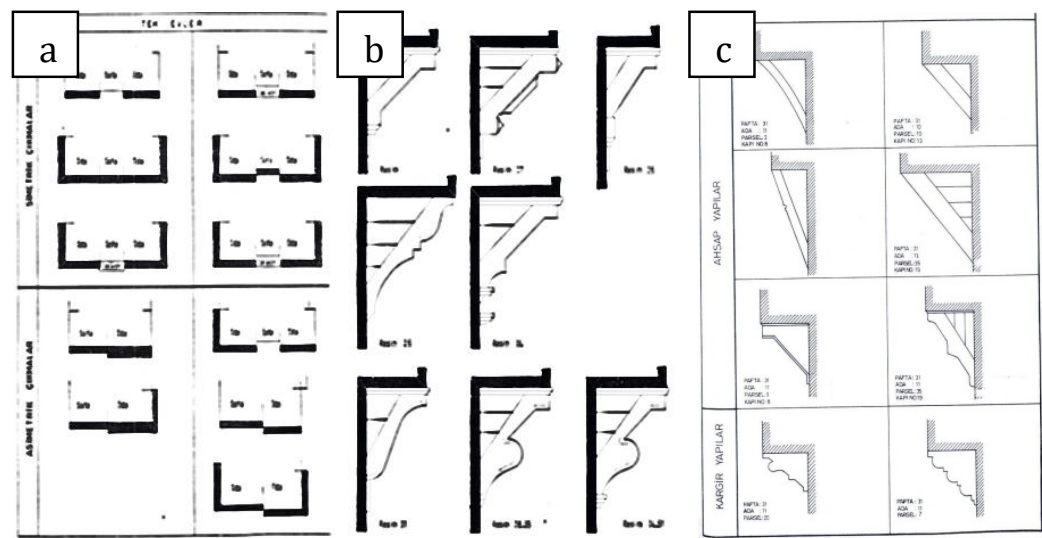

Windows

Although sash windows that are the period's traditional system are used in the traditional housing architecture of Şile, they are replaced by casement windows in some examples. The windows are placed on the façade as modules with a ratio of $1 / 2$. They are detached from each other with rhythmic gaps within the façade arrangement. In some very rare examples, the windows are emphasized in an integrated form. The sides of sash windows with lintel are usually enclosed with an $8-10 \mathrm{~cm}$ wide molding. In some examples the lower molding is decorated with various profiles (Fig.24) (Göktaş, 1992).
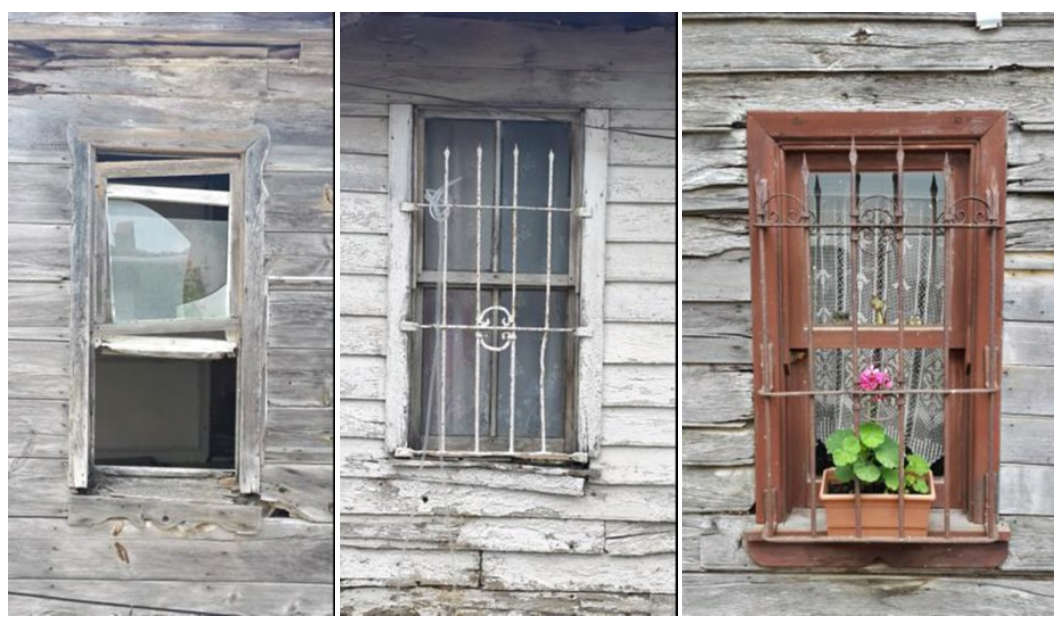

Entrance doors

The entrance doors of the traditional houses of Şile are usually double-winged (Fig.25: a).In most examples there are sky-lights letting the light into the space. The doors are mostly paneled and
Figure 23. a) Cantilevers typologies in wood structures (Göktaş, 1992, p. 49; Tab. 5). b) Buttresses typologies in wood structures (Göktaș, 1992, $p$. 51; Table). c) Buttresses typologies in wood structures (Teker, 1992, $p$. 37; Table 5).
Figure 24. Examples of windows from the area on the left, building inventory 97 , building inventory no. 96 in the middle and building inventory no. 128 on the right (Photo; Aydın, 2017). 
are surrounded with approximately $9 \mathrm{~cm}$ wide wooden sills (Göktaş, 1992, p. 62-63). Wooden thresholds are placed below the doors (Fig. 26) (Teker, 1992, p. 41).

There are small windows on both sides of the door to supervise the entrance door and to illuminate the space. In some examples the entrance door may be in a niche. When the niche is not wide enough, these small windows are moved to the side walls of the room and are used for the supervision of the entrance (Göktaş, 1992, p. 62).

It is possible to classify entrance doors in Şile under two groups according to their location on the façade;

-Entrance doors located on the middle axis of the building

-Recessed entrances

-Entrances without niches

- Entrance doors located on one side of the façade

-Below the cantilever

-Next to the cantilever (Fig.25: b).

Figure 25. a) Types of entrance doors in wooden buildings (Göktaş, 1992, p. 64; Table 8). b) Types of door entrances in wooden structures (compiled from Göktaș).

Figure 26. Examples of doors from the area; on the left, building inventory 97, building inventory no. 133 in the middle and building inventory no. 45 on the right (Photo; Aydın, 2017).
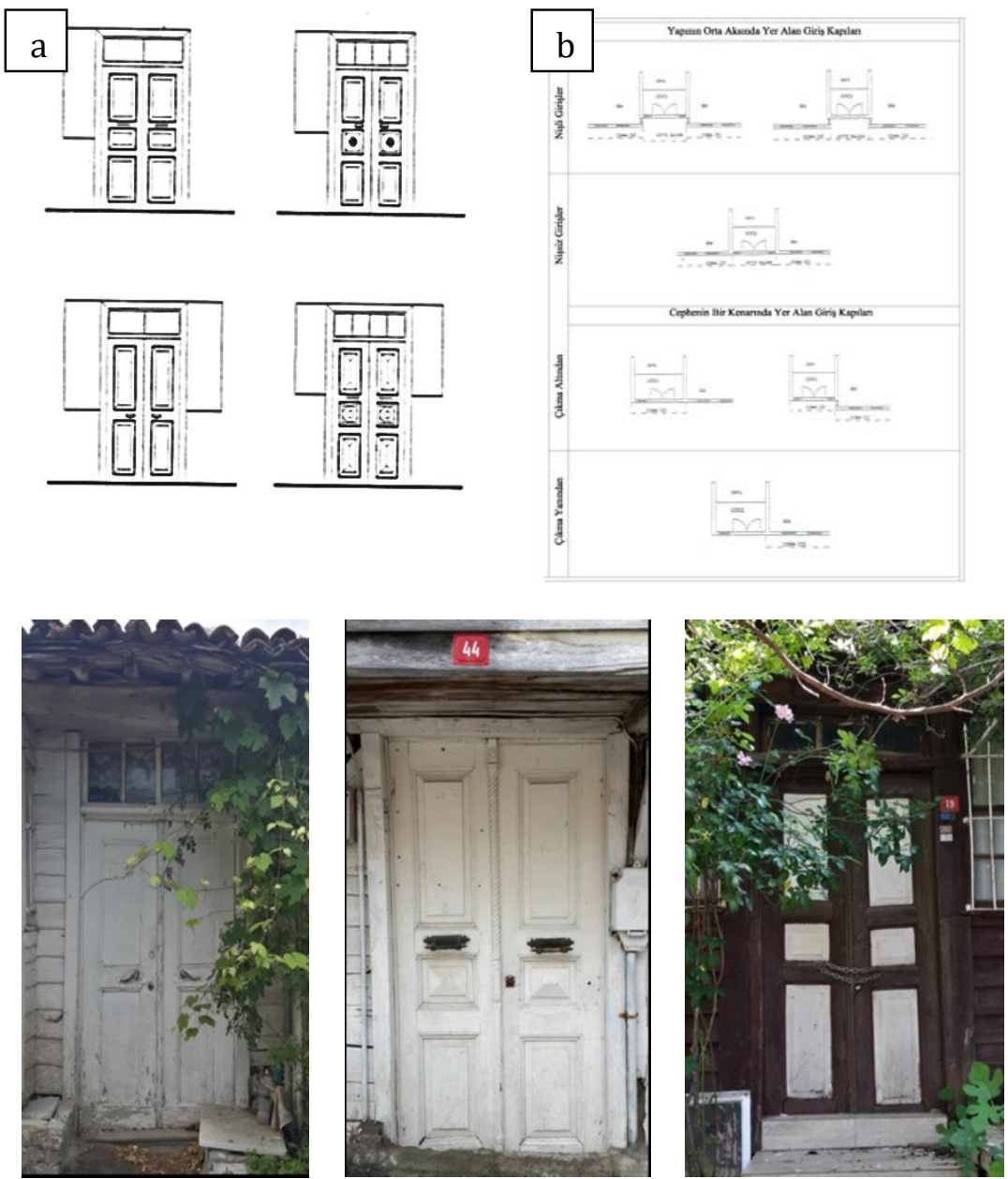


\section{Building Techniques and Materials}

The basic material used for civil architecture in Şile is wood (Temir, 2010, p. 116; Göktaş, 1992, p. 76; Teker, 1992, p. 47). The buildings are mostly constructed on a stone wall acting as a foundation and reaching the plinth level. Loadbearing wooden frames are filled with mudbrick made of straw and mud (Fig. 27) (Göktaş, 1992, p. 76-77).

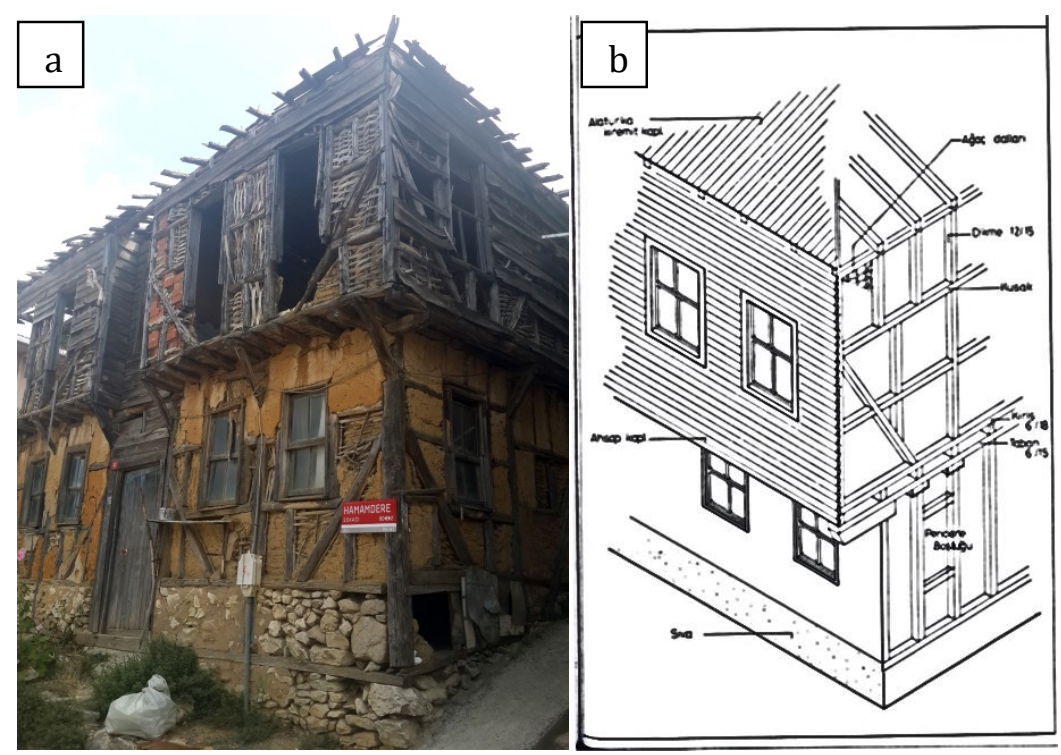

The gaps between the wooden frameworks is woven with chestnut branches and then plastered with a mortar made of a mixture of mud and straw.

The common roof style in the region is hipped and gabled roof. The roof coverings have wooden structures and are covered with pantiles.

\section{DETERMINATION WORK CARRIED OUT IN THE BALIBEY DISTRICT}

In the study carried out in the Fener neighborhood of Şile Balibey district, urban space analyses were carried out to document the present state, to determine and synthesize problems and potentials. 137 buildings and lots were evaluated within the scope of this work. During the analyses, all buildings were evaluated regardless of their characteristics, originality or state of registration. Urban space analyses were interpreted over $1 / 1000$ scale drawings with the help of incoming data, graphics and tables. The analysis work includes the following:

Environmental values analysis: In this analysis urban elements such as streets determining building blocks, traffic flow direction, paving materials, vista points, traffic signs, electricity, water and telephone poles, manhole covers, garbage containers and trees were identified and marked on the drawings (Fig.28).
Figure 27. a) The building located at Hamamdere Street no: 44 (Photo; Aydin, 2017). b) Construction techniques and materials in wooden structures (Teker, 1992, p. 45; Table 9). 
Figure 28. Environmental Analysis. (Drawing: Aydın, 2017).

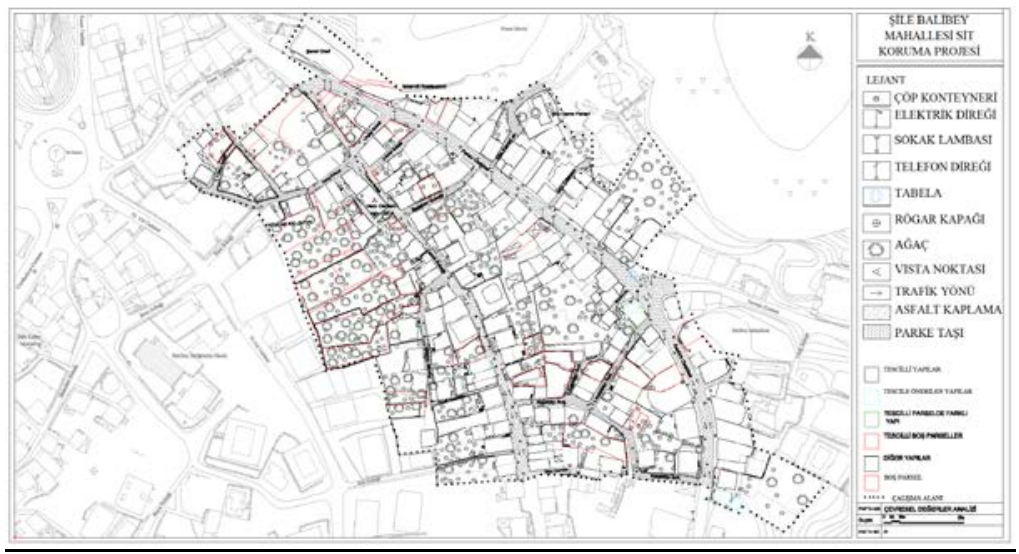

Plot analysis: The map of the area prepared by the municipality was superposed with the cadastral map and its relation to the present state was determined. The plots were classified as empty plots, registered plots and registered empty plots. Blocks, plots, door numbers and building entrances were determined and marked.

Entrances analysis: This was the analysis that determines the roof types, entrances and door numbers in the area. When the roof types were evaluated, it was seen that the roofs of new buildings, especially the ones on Fener Road did not comply with the provisions of the Conservation Master Plan. There were penthouses and terraces. Access to the plots that were not connected to the street was provided by connections through the plots that have street access.

Traffic analysis: Fener Road is the densest axis that connects the work area to the town center. There are four dead-ends in the area: Güz Çıkmazı (dead-end), Sarp Çıkmazı and two others without a name. As a natural result of the topography and the land subdivision, curvy and narrow pedestrian ways (pathways) are formed (Fig.29).

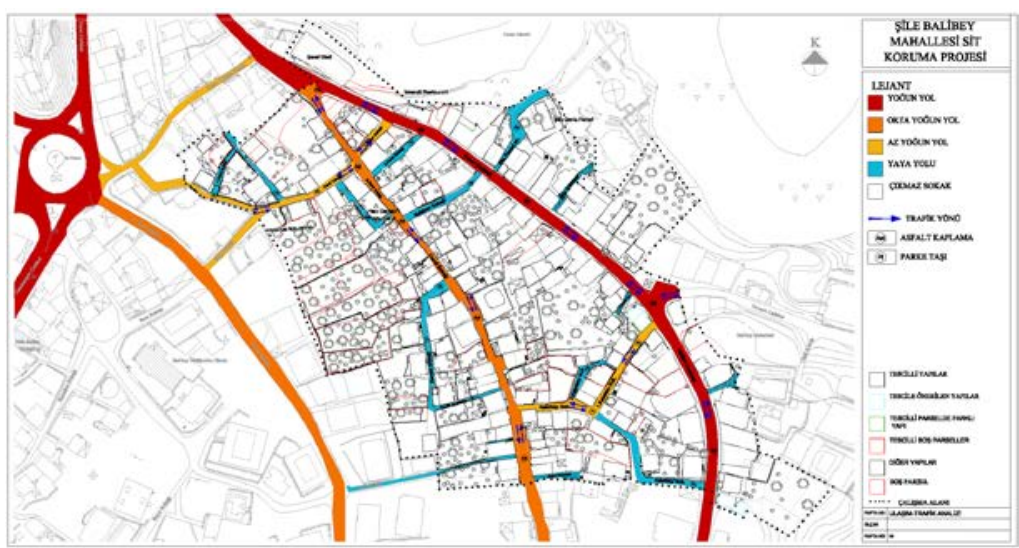

Figure 29. Traffic Analysis (Drawing: Aydın, 2017). 
Spatial analysis: Within the scope of this analysis, it was determined that plots with large gardens create dense emptiness whereas contiguous building groups on the Fener Road create denseness in the area (Fig.30).

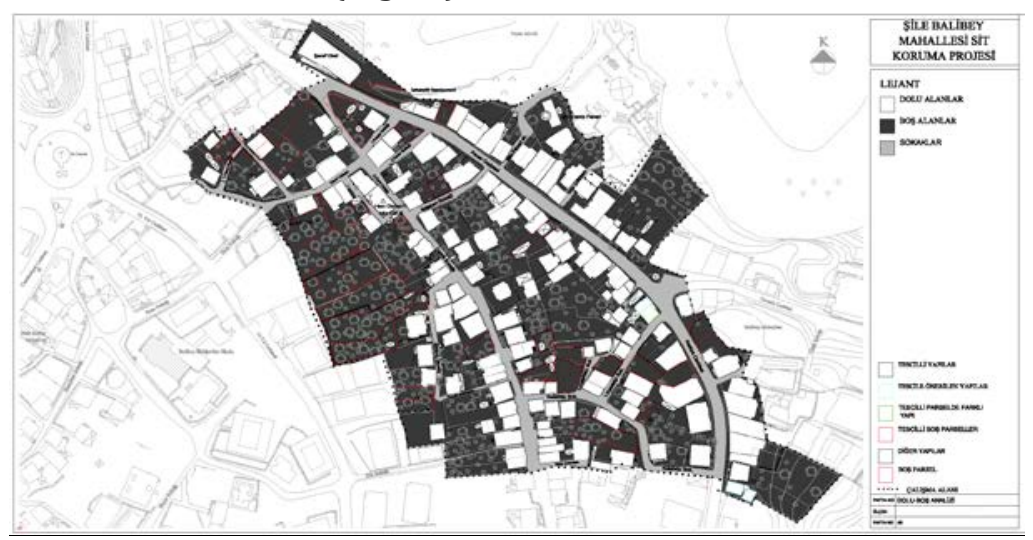

Ownership analysis: As a result of the assessment made in the area studied 133 buildings were determined to belong to individuals and 4 buildings were public property.

Legal status analysis: Analysis of the registration status of buildings in the said area determined that out of 137 buildings, 50 buildings were registered. 3 of the registered buildings were abandoned. There was 1 registered empty plot, 1 registered plot with a different building and 2 buildings proposed for registration in the area (Fig.31).

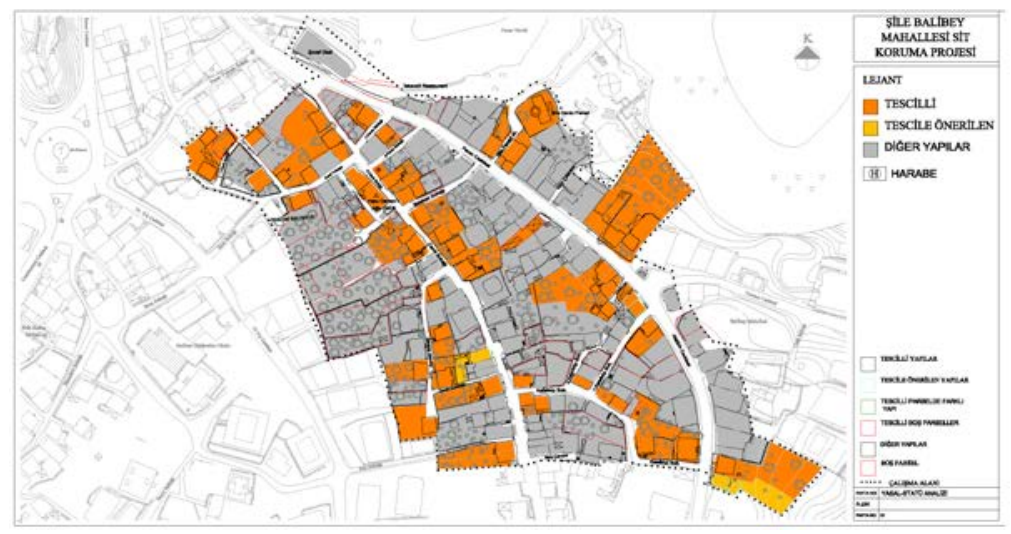

Land use analysis: When the functions of the buildings were considered the following building types were found in the area: housing, housing + trade, accommodation, accommodation + trade, religious, lighthouse/museum, fountain, housing/parking, housing + parking + trade, ruin (housing), worksite.

Number of floors analysis: The analysis of the number of floors determined that high-rise buildings were on the Fener Road and spread into the side streets. The Cami Street which is in the interior of the area is the axis where low-rise buildings form the majority. The breakdown of the buildings according to number of
Figure 30. Spatial Analysis (Drawing: Aydın, 2017).

Figure 31. Legal Status Analysis (Drawing: Aydın, 2017). 
floors: Ground (\%9), Ground +1 (\%57), Ground +2 (\%22), Ground $+3(\% 10)$, Ground +4 (\%1), Ground +6 (\%1) (Fig.32).

Figure 32. Number of Floors Analysis (Drawing: Aydin, 2017).

Figure 33. Construction System and Material Analysis (Drawing: Aydın, 2017).

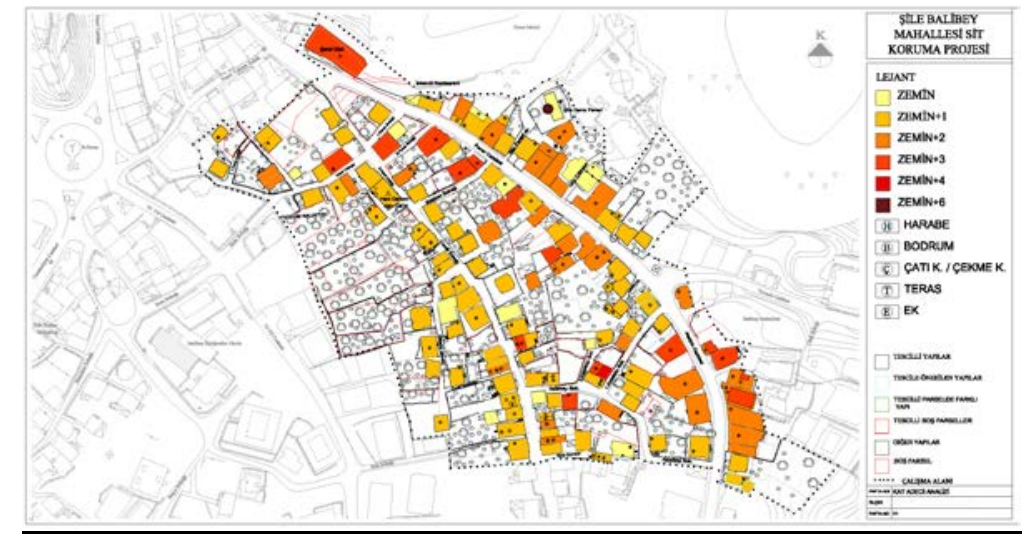

Construction system and material analysis: The following was observes in the evaluation of the buildings within the area with respect to construction techniques: $62 \%$ reinforced concrete, $23 \%$ wooden framed, $12 \%$ reinforced concrete + wood, $2 \%$ stone and $1 \%$ stone + wood (Fig. 33 ).

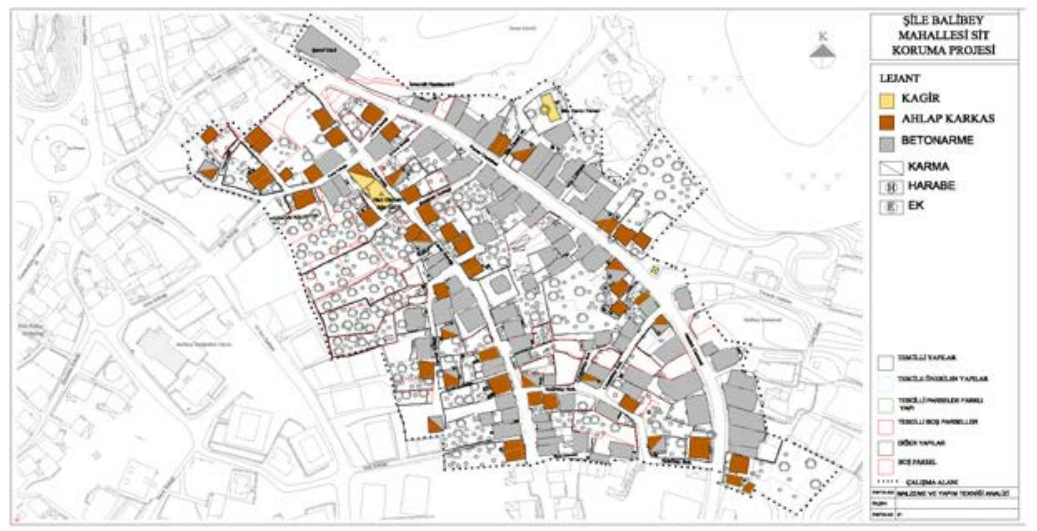

Structural condition analysis: Evaluation with respect to structural status determined that $12 \%$ pose danger in terms of load-bearing systems and were unusable. Most of these buildings were abandoned and there was no one living inside them. The walls, roofs and floors of the ruined buildings that form $2 \%$ of the area, have collapsed and there is very little left of (Fig. 34). 


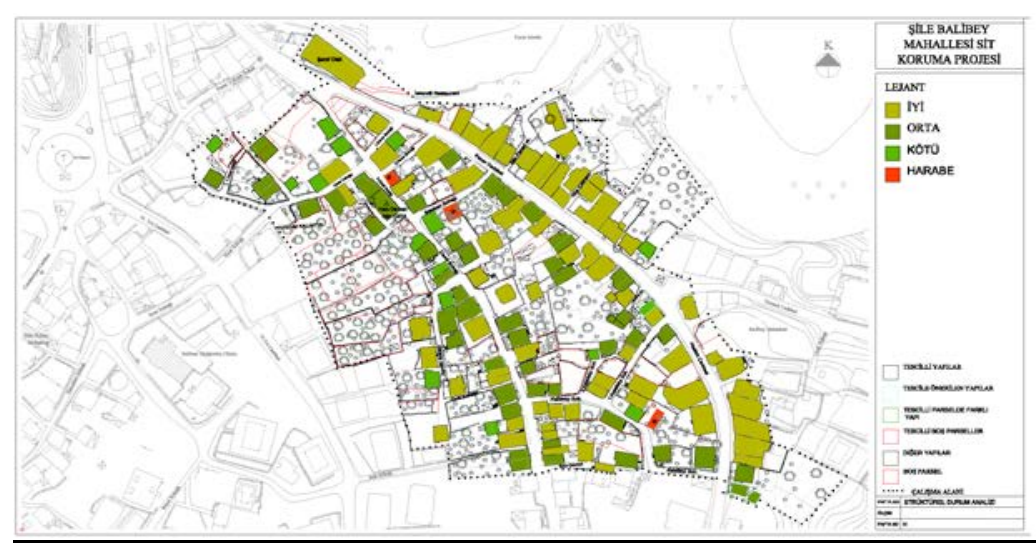

Evaluation of cultural property analysis: The registered buildings were evaluated with regard to originality and wholeness values and almost half of the 50 registered buildings and 2 buildings proposed for registration were determined not to be in a good state of conservation. 48 buildings out of 137 are well adapted to the original urban texture in terms of position on the plot, number of floors, ratios of façade and similar characteristics. 37 buildings on the Fener Road are noncompliant with the area and the topography with their number of floors, usage of plot and façade ratios (Fig.35).

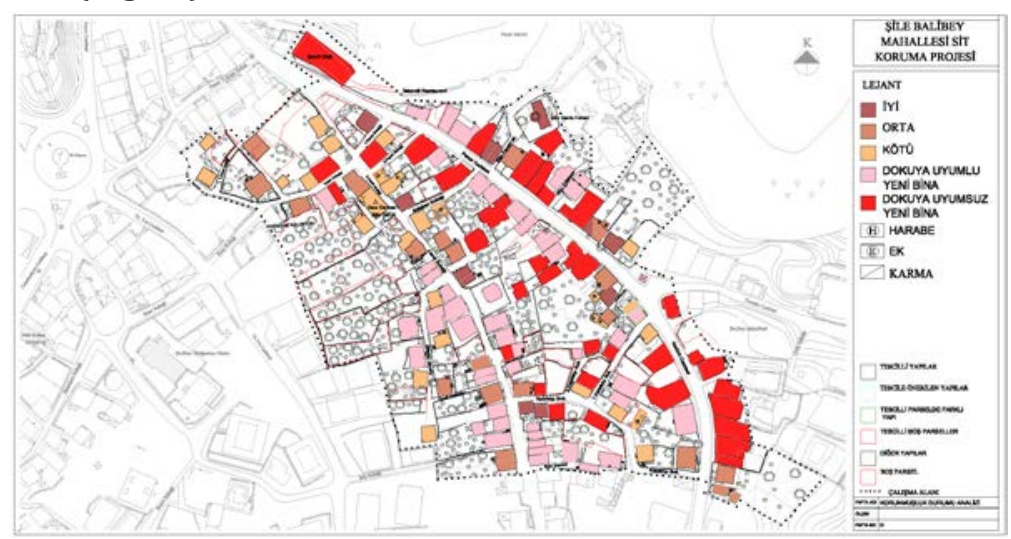

Use of building stock analysis: It was determined that 101 buildings in the said area at the Balibey district use $74 \%$ of the area. 7 buildings were used partially, and 4 buildings were used seasonally. Besides these, 2 buildings were worksites and 3 buildings were in ruins.

Chronological analysis: There are 2 monumental works valuable in terms of history in the area: The Şile Lighthouse built in 1859 and the Hacıosmanağa Mosque that is an Ottoman monument. The buildings, examples of civil architecture in the area, are believed to be 100-150 years old (Fig.36).
Figure 34. Structural Condition Analysis (Drawing: Aydın, 2017).

Figure 35. Evaluation of Cultural Property Analysis (Drawing: Aydın, 2017). 
Figure 36. Chronological Analysis (Drawing: Aydın, 2017).

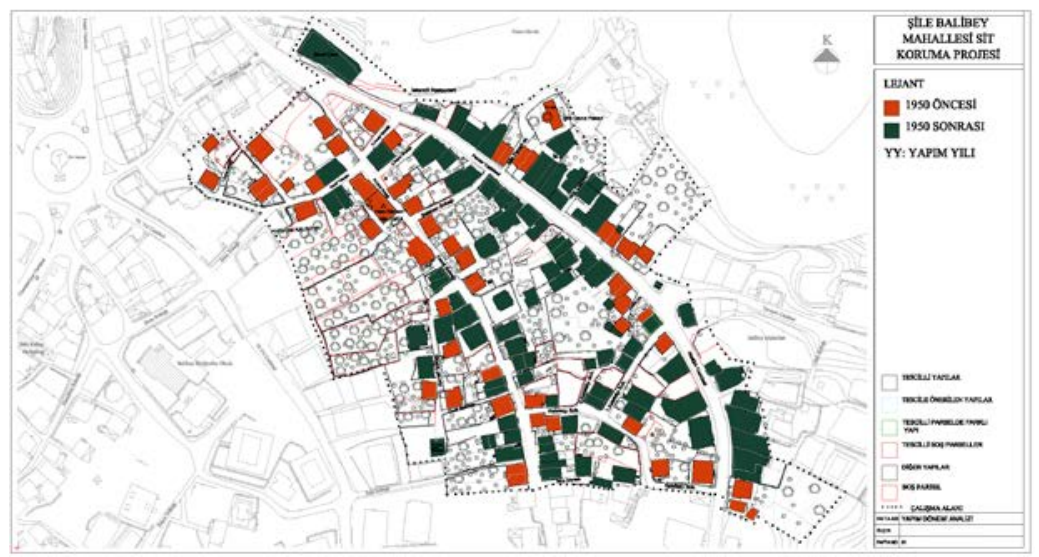

EVALUATION OF THE CHANGE

The main reasons behind the changes in the historical urban texture of Şile are the uncontrolled growth and the pressure of tourism for which the town is not ready. There are threats on preserving and carrying into future the abstract and tangible cultural heritage that reached the present. The study tried to determine these threats.

\section{CHANGES IN THE URBAN TEXTURE}

- With the immigration of the Greek population living in the center and villages of Şile as a result of the Turkish-Greek Population Exchange that was signed in the first quarter of the 19th century, Şile underwent a radical change culturally and economically and the texture of the town started to change (Goularas, 2010, p. 78).

- The fate of the settlement that transformed the transportation problems into an advantage and preserved the settlement's original structure and texture changed with the construction of the Istanbul-Şile highway in the 1990's and went under the threat of the secondary residence and opened to tourism.

- Another reason for the town to open to tourism uncontrollably is the Master and Implementary Development Plans that were prepared to help the development of tourism and approved in 1991. As a result of these plans the urban site was imperiled.

- With the increase in the demand of tourism, in the 1980's the economic, social and cultural structure developed rapidly. Consequently, in the Hacıkasım and Balibey districts, especially on the shore line, unearned income increased, and the houses started to rapidly change hands.

- Another radical change that took place in the urban texture of Şile was the harbor area that was filled and left to its fate in 1990. With this filling, the salvage buildings that are among the monuments of Şile lost their rescue function realized for many years. 


\section{CHANGES IN THE BUILDINGS}

- Despite new conditions for housing in the notes of the 1992 plan, when the allowed height for buildings was determined, the registered buildings were not used as reference. Instead elevation differences were used. These neighboring buildings that were constructed without the reference of the registered buildings were the most important factors in the increase of the destruction of the texture.

- Despite the clause in the notes of the 1992 plan stating, "attic floors cannot be acquired", the roof and half storeys that were realized affect the shoreline and the wholeness of the texture.

- With the new buildings, there were critical changes in the usage of blocks and plots. With the current new buildings, attempts were made to use the plots fully and consequently the texture system that had developed organically was left aside and original applications were used in which buildings that can be reached through each other or their gardens were created. Plots that were once used as vegetable gardens or orchards were left empty in time.

- In the usage of plots on the Fener axis, buildings with characteristics such as uncontrolled floor heights, façade ratios, etc. that did not comply with the urban texture and topography emerged.

- When the interventions on the registered buildings of the area were analyzed and evaluated in terms of structure, it was determined that $12 \%$ of them were dangerous in terms of load bearing systems and were uninhabitable.

- Another problem in the area was the damage to the structural and aesthetic wholeness of the twin buildings due to the separation of ownership. While one part of these buildings was preserved, the other part of the building was left to its fate. This causes a conservation problem.

- The traditional houses that are still inhabited went under spatial changes to reach modern comfort requirements and their plan compositions were damaged by additional spaces.

- When the conservation status of the registered buildings in the area was evaluated, the traditional and original architectural characteristics of the area such as original construction system of the buildings, façade systems, original building material, roof type and coating material were analyzed. Consequently, it was determined that out of the 50 registered buildings, originality and wholeness was not conserved in $40 \%$ and $34 \%$ were partially original. 


\section{INTERVENTION PROPOSALS}

\section{Proposals Regarding the Urban Texture Scale}

- Today, $15 \%$ of the buildings in the said area are either empty or abandoned and $2 \%$ are in ruins. In the work area, housing or boutique hotel functions are proposed for these buildings to prevent the pressure of secondary housing, to stop the increase in the number of summer houses and to provide a controlled economic support for the owner.

- Urban texture should be used with all its components in the most effective and productive way. The unused vegetable gardens and orchards and passive green areas must be rehabilitated for active usage. Otherwise, these areas are under the risk of zoning for construction. The gardens must regain their original functions and organic production must be encouraged and supported.

- The vehicle traffic in the area must also be revised. It is important to pedestrianize the Fener-Atatürk road in terms of the planned urban layout. The alternative axis for the FenerAtatürk road is the 75th Year road. This redirection aims at the Şile Cultural Center located outside the area at the end of the Atatürk Road, not a very busy place, to host cultural and art activities. The Çamlı Tea garden and picnic areas are located at the continuation of this axis that was created. These can also present a recreative function to the area (Fig.42).

- To provide for the need of parking space, it was proposed to arrange the parking in front of the Maşatlık Park as a pocket parking for short-term parking for visitors coming from Fener Road. For visitors coming from the Atatürk Road direction, the presently empty lot on block 63 plot 29 was arranged as a

${ }^{21}$ For the parking problem existing throughout the town, the "Town Square and Multi-Storey Car Park Project" carried out jointly by the Şile and Istanbul Municipalities is believed to provide a solution. The expectations about this project include not only a car park but also a space, which is the town square that will be designed, where the town people will gather and sustain the town culture. http://www.sile.bel.t r/Page/Detail/8663, access date 03.08.2017. short-term parking21.

- Redirection to two main axes in the work area where the historical texture is continuous is proposed. The Şeref Hotel located at the beginning of Fener Road, one of these axes, must be pulled down and replaced by a view terrace so that the monuments of the town will be viewed panoramically from this terrace. Şile Fortress, Maşatlık Park-Greek Cemetery and Şile Lighthouse can be viewed from a single spot.

- Re-functioning of the buildings on Fener axis and creating refreshment spaces required by the area will revive trade. This axis must serve the housing + trade functions. On another axis, the Cami Street many buildings with large gardens are either abandoned or neglected. With restorations along the street a qualified axis will be created. House-guesthouse type buildings where main user and guests will meet are proposed (Fig.39). 
- The ruins of a hammam, believed to be from the Byzantine period, located on the Cami Yokuşu Street, block 51 plot 8, is proposed to be unearthed and used as both an exhibition and recreation area (Fig.41).

- Besides exhibiting the natural and historical environment of Şile, the town, which is rich in archeological finds also, needs a museum building to exhibit these. It is proposed to include a museum building in the project called "Şile Harbor Renovation and Recreation Project" run by the Şile municipality to transform the harbor into an active tourism area covering an area of 120 thousand square meters.

\section{Proposals Regarding Single Building Scale}

- The intervention proposals for the registered and suggested for registry civil architecture buildings are: maintenance, simple repair, restoration and reconstruction.

- New buildings are evaluated in terms of being compatible or incompatible with the urban texture. While pulling down or decreasing the number of storeys were proposed for the incompatible buildings, for the buildings compatible with the texture intervention proposals on their facades and roofs were made (Fig.37; Fig. 38).

- Cami Street was chosen as a pilot axis in the area for this study. In the silhouette work on the Cami Street, proposed intervention decisions were reflected on the project. Besides simple repair decision such as color changes, material changes and completion on the facades, intervention decisions such as removing or adding storeys, removing late period additions or changes in the façade system were dealt with on the single building scale. Additionally, decisions such as reconstruction of the buildings that have not survived, infill design or removing some buildings were indicated on the silhouette work (Fig.43, 44, 45, 46).

- As a result of studies carried out in the Balibey district, it was determined that the present built-up areas are saturated. Therefore, further housing in the area must not be allowed and the present building stock must be used effectively. If housing continues, new buildings will cause the vegetable gardens and orchards to disappear. When the buildings complete their useful economic lives, housing compatible with the historic texture with modern design criteria are proposed on these plots. The proposals are presented as plan marks. Gentrification proposals for the pavements and width of Fener Road were also made (Fig.41). 
Figure 37. Single Structure Intervention proposal Analysis (Drawing: Aydın, 2017).

Figure 38. Number of Floors Proposal Analysis (Drawing: Aydın, 2017).

Figure 39. Use of Building Stock Proposal Analysis (Drawing: Aydın, 2017).

Figure 40. Intervention Porposal Analysis-I (Drawing: Aydın, 2017).
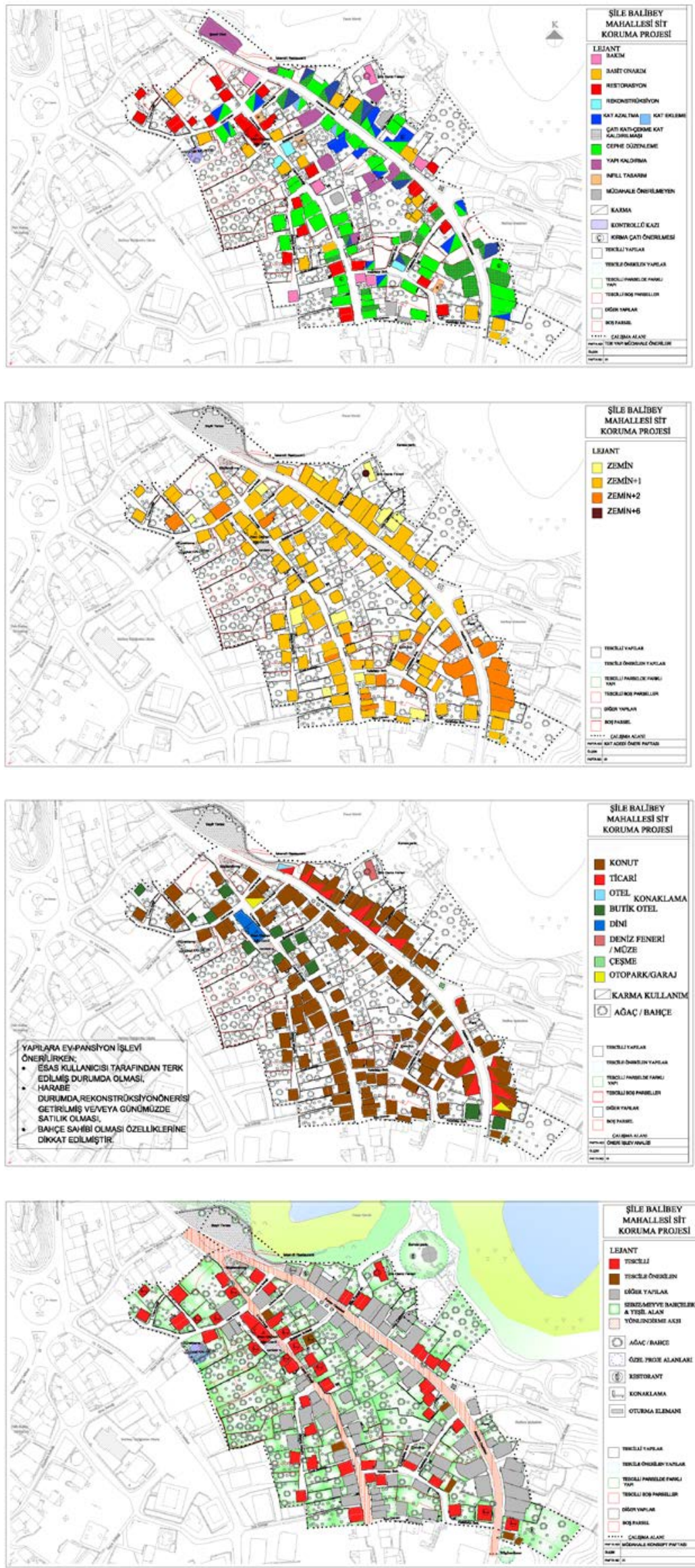

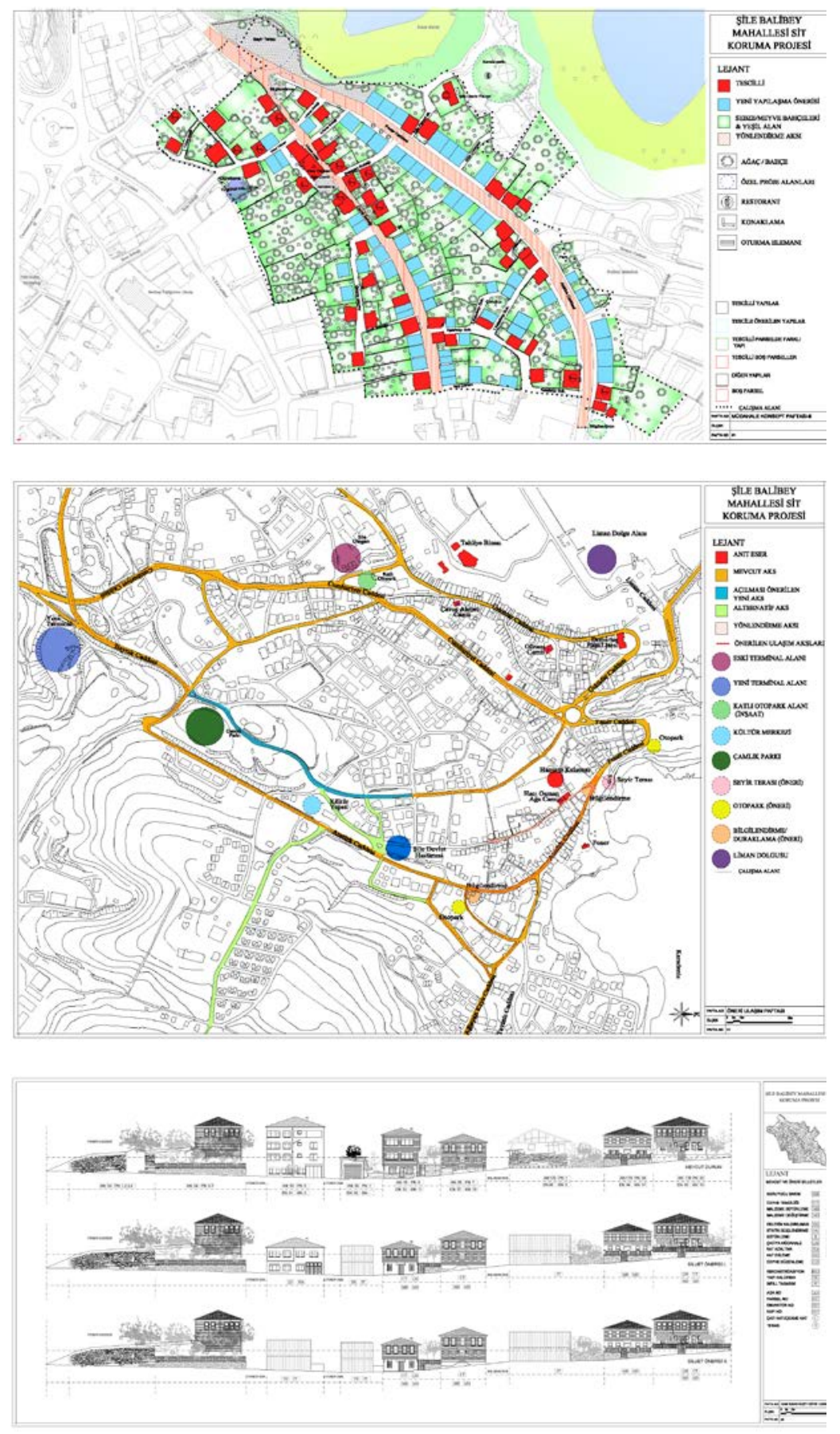

Figure 41. Intervention Porposal Analysis-II (Drawing: Aydın, 2017).

Figure 42. Traffic Proposal Analysis (Drawing: Aydın, 2017).

Figure 43. Silhouette 1 Cami Street North Facade Proposal (Drawing: Aydın, 2017).

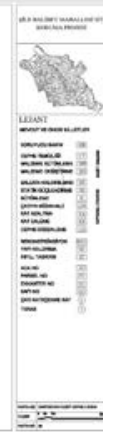

Figure 44. Silhouette 2 Cami Street North Facade Proposal (Drawing: Aydın, 2017). 
Figure 45. Silhouette 1 Cami Street South Facade Proposal (Drawing: Aydin, 2017).

Figure 46. Silhouette 2 Cami Street South Facade Proposal (Drawing: Aydin, 2017).
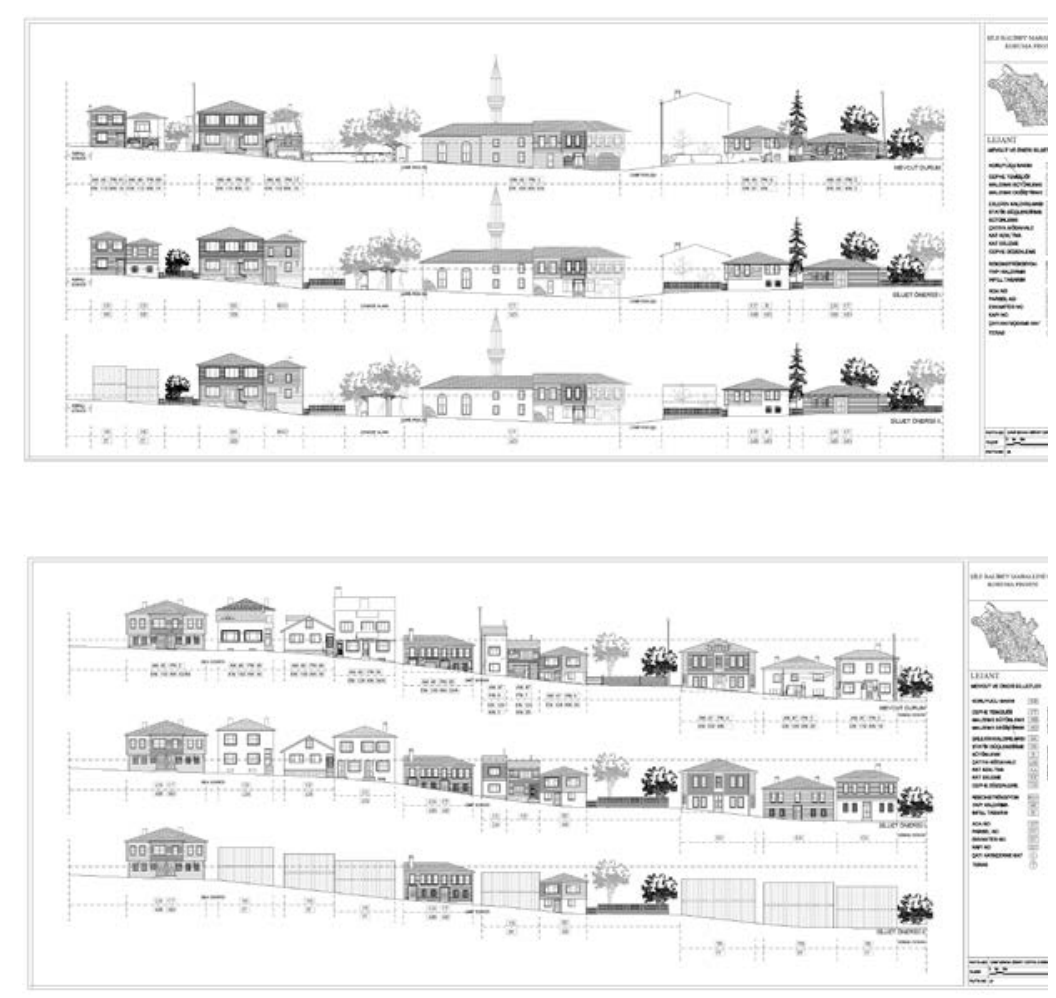

\section{CONCLUSION}

An original urban texture reflecting the architectural characteristics of the 19th and 20th centuries was created in Şile that was inhabited by different civilizations and societies due to its location. However, in the 1980's rapidly developing transportation facilities and value increase, reinforced concrete structures started to emerge in the historical urban texture. Although the notion of conservation first came up in the 1990's, the desired level of conservation was not reached. The goal for the future must be to create an environment meeting modern comfort requirements and integrating with the city while preventing further destruction of the original structure of the site area and to sustain the city with its natural, archeological and urban sites.

Şile has not been touched upon in a comprehensive academical or scientific paper so far despite its rich architectural and urban heritage. Importance of this paper is that urban protected area of Sile has been presented to the attention of the architects, art and architect historians, and other specialists working on this field in a scientific paper firstly. In addition, this study includes determination of approximately 50-year-long unfavorable changes in the architectural and urban heritage of Şile, and protection proposals from now to the future. 


\section{REFERENCES}

Aksel, A. (1995). Şile İlçesi Maddesi. İstanbul Dergisi, 13, 18.

Aydın, B. (2017). Şile Balibey Mahallesi Sit Koruma Projesi. (Yüksek Lisans Tezi).İstanbul Teknik Üniversitesi, Fen Bilimleri Enstitüsü, İstanbul.

Aygün, H. G. (2010). Geçmişten Günümüze Tahlisiye Teşkilatı (Cankurtarma) ve Şile. İçinde H. Ansal (Editör), Ufukta Bir Işık. Uluslararası Deniz Fenerleri Sempozyumu. Şile Feneri'nin 150. Yll Kutlamaları 12-13 Haziran 2010, (p.8192). İstanbul: Işık Üniversitesi Yayınları.

Demirel, E. (2011). Türkiye Deniz Fenerleri Atlası Özel Koleksiyonu 2011. Atlas Keşif Kitaplığı, İstanbul: Doğan Burda Yayınevi.

Dinç, B. (2013). Teksen Hisarı. Aktüel Arkeoloji, 33,36-39.

Dinçer, İ., Enlil, Z., Evren, Y. ve Kozaman-Som, S. (2011). İstanbul'un Tarihi ve Doğal Miras Değerleri: Potansiyeller, Riskler ve Koruma Sorunlarl. İstanbul: İstanbul Bilgi Üniversitesi Yayınları.

Erarslan, S. (2010). Şile: Bir Denizkızı. İstanbul: Heyamola Yayınları.

Ertek, T. A., Kozak, R. \& Evren, N. (1998). Şile: Doğal Tarihi ve Kültürel Yapısı, Sosyo-Ekonomik Analizi ve Gelişme Stratejileri. İstanbul.

Fıratlı, N. (1952). Şile ve Kalealtı. TTOK. 18-20.

Goularas, G. B. (2010). Mübadele ve Şile. İçinde H. Ansal (Editör), Ufukta Bir Işık. Uluslararası Deniz Fenerleri Sempozyumu. Şile Feneri'nin 150. Yıl Kutlamaları 12-13 Haziran 2010, (p.73-79). İstanbul: Işıı Üniversitesi Yayınları.

Göktaș, A. (1992). Şile'de Tarihsel Araştırma ve Çevre Koruma Çalışmaları (Hamamdere ve Balibey Mahalleri). (Yüksek Lisans Tezi).Yıldız Teknik Üniversitesi, Fen Bilimleri Enstitüsü, İstanbul.

Güner, R. (2013). Sürdürülebilirlik Bağlamında Şile Kent Dokusu Analizi Camcı ve Cami Sokakları. (Yüksek Lisans Tezi). M. S. G. S. Ü., Fen Bilimleri Enstitüsü, İstanbul. İstanbul Çevre Durum Raporu,

Kasar, N. (1987). Şile İlçesinin Turizm Potansiyelinin İncelenmesi.(Yüksek Lisans Tezi). İstanbul Üniversitesi, Sosyal Bilimler Enstitüsü, Turizm Anabilim Dalı, İstanbul.

Kolçak, E. S. (2010). Osmanlı Döneminde Şile Feneri. İçinde H. Ansal (Editör), Ufukta Bir Işık. Uluslararası Deniz Fenerleri Sempozyumu. Şile Feneri'nin 150. Yll Kutlamaları 12-13 Haziran 2010, (s.93-103). İstanbul: Işık Üniversitesi Yayınları.

Muslu, G. (1999).Şile Şehri. (Yüksek Lisans Tezi). İstanbul Üniversitesi, Sosyal Bilimler Enstitüsü, İstanbul. 
Özdoğan, M. (1982a). Doğu Marmara ve Trakya Araştırmaları. TAD, 26, 37-62.

Özdoğan, M. (1982b). Trakya ve Doğu Marmara Araştırmaları 1981 Yılı Çalışmaları. KST, 4, 137-142.

Özdoğan, M. (2014). İstanbul'un Tarih Öncesi. Aktüel Arkeoloji, $37,36-45$.

Özdoğan, M. (2016). İstanbul'un Tarihi Yarımada Dışı Coğrafyasında Göz Ardı Edilen Tarih öncesi Kültürler. Mimar.ist, 57, 18-22.

Seri, B. (1994). Deniz Fenerleri. Dünden Bugüne İstanbul Ansiklopedisi 3. İstanbul: Kültür Bakanlığı ve Tarih Vakfı Ortak Yayını.

Şarlak, E. (2010). Hatıralardaki Özlem: Şile'den Göç Eden Rum'ların Belleklerindeki İzler. İçinde H. Ansal (Editör), Ufukta Bir Işılk. Uluslararası Deniz Fenerleri Sempozyumu. Şile Feneri'nin 150. Yıl Kutlamaları 12-13 Haziran 2010, (p.59-72). İstanbul: Işık Üniversitesi Yayınları.

Şile Tanıtım Kitabı.(1995). Şile Belediyesi Tanıtım Broşürü. İstanbul, Şile.

Tapan, M. (1990, 23 Aralık). Şile'yi SíT Kararı Kurtaracak. Cumhuriyet Gazetesi, s.15, İstanbul: İBB Atatürk Kitaplığı.

Teker, T. (1992). Şile'de Tarihsel Araştırma ve Çevre Koruması.(Yüksek Lisans Tezi).Yıldız Teknik Üniversitesi, Fen Bilimleri Enstitüsü, İstanbul.

Temir, Ş. R. (2010). Geçmişten Günümüze Şile ve Şile Bezi (Şile and Şile cloth from past to present). (A. Roome Çev.).Ankara: T. C. Kültür ve Turizm Bakanlığı.

Toroslu, M. V. (2009). "Denizciye Göz Kırpan Sevdalar" Deniz Fenerleri.İzmir: Dev Yayıncıllk.

Umar, B. (1993). Türkiye'deki Tarihsel Adlar. İstanbul: İnkilap Yayınevi.

Umar, B. (2004). Bithynia. İstanbul: İnkilap Yayınevi.

Uykucu, K. E. (1973). Cumhuriyetin 50. Yılında İlçeleriyle Birlikte İstanbul. İstanbul: Kahraman Yayınları.

Url-1<http://www.aktuelarkeoloji.com.tr/sarikavak-kalesi>, access date 20.03.2017.

Url-2<http://www.envanter.gov.tr/anit/kentsel/detay/40797>, access date 20.03.2017.

Url-3<http://www.envanter.gov.tr/anit/kentsel/detay/40812>, access date 20.03.2017.

Url-4<http://www.envanter.gov.tr/anit/kentsel/detay/40959>, access date 20.03.2017.

Url-5<http://www.envanter.gov.tr/anit/kentsel/detay/41097>, access date 20.03.2017.

Url-6<http://www.envanter.gov.tr/anit/kentsel/detay/49128>, access date 20.03.2017. 
Url-7<http://www.envanter.gov.tr/anit/kentsel/detay/49137>, access date 20.03.2017.

Url-8<http://www.envanter.gov.tr/anit/kentsel/detay/49172>, access date 20.03.2017.

Url9<http://www.istanbulkulturenvanteri.gov.tr/anit/kentsel/d etay/49126>, access date, 20.03.2017.

Url-10<http://www.sile.bel.tr/Page/Detail/8663>, access date 03.08.2017.

Url-11<http://silekizteknik.meb.k12.tr>, access date 20.03.2017.

Url-12<http://www.turkiye-haritasi.net/istanbul-haritasi.html>, access date; 29.04.2017.

\section{Resume}

Betül Aydın Cura got associate degree from Restoration Department of Zonguldak Karaelmas University Safranbolu Vocational School of Higher Education in 2007. She graduated from Faculty of Architecture of Istanbul Technical University in 2011 and completed her post-graduate study in Restoration Program in Istanbul Technical University in 2017. After working in hotel construction projects between 2011 and 2013, she was employed as project supervisor in a company, which developed restoration projects for several public foundations and institutions, between 2013 and 2018. Now, she continues her professional works in her own company BAC Architect and Restoration she founded in 2018.

Kemal Kutgün Eyüpgiller is a Professor of Architecture, and Dean of the Faculty of Architecture at Istanbul University - Turkey. He holds M.Sc. and Ph.D. degrees in Restoration from Istanbul Technical University. His areas of interest include restoration and conservation of historic monuments, urban conservation, Ottoman military architecture and urban history. Prof. Dr. Eyüpgiller is the author of numerous scientific papers and books. 